\title{
Non-target toxicity of novel insecticides
}

\author{
Vedran Mužinić and Davor Želježić \\ Mutagenesis Unit, Institute for Medical Research and Occupational Health, Zagreb, Croatia
}

[Received in February 2018; Similarity Check in February 2018; Accepted in May 2018]

\begin{abstract}
Humans have used insecticides since ancient times. The spectrum and potency of available insecticidal substances has greatly expanded since the industrial revolution, resulting in widespread use and unforeseen levels of synthetic chemicals in the environment. Concerns about the toxic effects of these new chemicals on non-target species became public soon after their appearance, which eventually led to the restrictions of use. At the same time, new, more environmentallyfriendly insecticides have been developed, based on naturally occurring chemicals, such as pyrethroids (derivatives of pyrethrin), neonicotinoids (derivatives of nicotine), and insecticides based on the neem tree vegetable oil (Azadirachta indica), predominantly azadirachtin. Although these new substances are more selective toward pest insects, they can still target other organisms. Neonicotinoids, for example, have been implicated in the decline of the bee population worldwide. This review summarises recent literature published on non-target toxicity of neonicotinoids, pyrethroids, and neem-based insecticidal substances, with a special emphasis on neonicotinoid toxicity in honeybees. We also touch upon the effects of pesticide combinations and documented human exposure to these substances.
\end{abstract}

KEY WORDS: neonicotinoids; pyrethroids; neem; azadirachtin; non-target toxicity

Since ancient times, humans have used insecticides to mitigate shortages in harvest potency (1). A major group of chemicals, broadly named pesticides, were introduced to agricultural practice exactly with the purpose to increase crop yield $(2,3)$. With time, their use has expanded to treating infestations in small animals (4), eradicating household insects (5), or preventing vector-borne infectious disease (6). With the beginning of industrial revolution came newly synthesised organic pesticidal compounds (7), whose widespread use soon increased the burden of synthetic chemicals on the environment. New problems began to arise, such as target species resistance (8) and non-target species toxicity $(9,10)$. Concerns about the adverse environmental impacts were aptly voiced in the book Silent Spring in 1962 (11). The first to be banned because of adverse effects on human health was DDT (12). This triggered a series of toxicological evaluations, many of which resulted in use restrictions or bans of environmentally excessively toxic and persistent substances.

Sustainable agriculture implies a set of practices to meet food and textile needs of the continuously growing world population without compromising the same need for future generations (13). One of these practices is the development and usage of new plant protection products based on naturally present compounds which protect plants against various pests and parasitic organisms. The pesticides that meet these requirements are referred to as "green" pesticides. They are expected to be effective, safe for non-

Correspondence to: Vedran Mužinić, Institute for Medical Research and Occupational Health, Ksaverska cesta 2, 10000 Zagreb, Croatia E-mail:vmuzinic@imi.hr target organisms, and biodegradable in the environment (14). Pyrethroids and neonicotinoids are two showcase groups of the new pesticides that meet those needs. They are more selective for pest insects, less toxic to mammals, and biodegrade better than synthetic pesticides, yet, ever since the report implying them in bee population declines and other adverse effects on non-target organisms they have come under public scrutiny $(15,16)$.

Another natural pesticide, neem, has been used in traditional medicine in India thanks to the alleged antimicrobial and antiparasitic effects of its oil (17). In addition, neem extracts have been known to possess insecticidal properties, the most potent among them being azadirachtin (18).

This review aims to provide an updated overview of non-target toxic effects of these three groups of insecticides.

\section{NEONICOTINOIDS}

Nicotine, a well-known extract of Nicotiana tabacum, has been used as aphicide for centuries. However, its insecticidal potency is low and narrow, whereas its acute toxicity to mammals is high (19). To overcome these limitations, pesticide research developed compounds which have become known as neonicotinoids. They act as nicotine acetylcholine receptor (nAChR) agonists to prolong insect neuron depolarisation and overstimulate their central nervous system, which eventually kills them. Many of them are intended for preemergent use. Considering their systemic nature, neonicotinoids spread into all the tissues of the emerging plant. Representative substances of this 
group are imidacloprid, acetamiprid, thiametoxam, thiacloprid, clothianidin, and dinotefuran.

Due to high selectivity for insect nAChRs, their acute toxicity is relatively low to mammals but is much higher if chronic.

\section{Effects on non-target insects of economic importance}

\section{Honeybees}

Honeybees are pollinator insects of great economic and ecological importance, but are susceptible to sublethal exposure to neonicotinoids. In 2006, honeybee keepers in the USA reported strange, inexplicable disappearances of honeybee drones from colonies, an event later named as "colony collapse disorder" (20). Since then, neonicotinoid insecticides were implicated as major culprits for the global honeybee and bumblebee population declines. Their systemic distribution throughout a plant, flowers and pollen in particular, poses a specific risk for pollinator insects (21). The risk of exposure also comes from consuming water polluted with neonicotinoids (22). Imidacloprid, acetamiprid, and clothianidin are very persistent water pollutants detected in biologically relevant concentrations even in treated wastewater (23). Honeybees could also be greatly exposed to neonicotinoid-containing particulate emissions stirred by drilling machines used in seeding (24).

The effects seem to vary by neonicotinoid type. In one study imidacloprid caused higher mortality in honeybees than acetamiprid (25). Thiacloprid, in turn, seems to impair their foraging behaviour, homing success, navigation performance, and social communication (16). Honeybee workers treated orally with sugar water containing imidacloprid delayed their return to the hives significantly (26). One meta-analysis (27) suggests that imidacloprid in nectar at field-realistic levels will have no lethal effects but will reduce the expected performance in honeybees by 6-20\%. Another study (28) reported that their overwintering success depended on the dose of imidacloprid exposure through pollen. Another, Canadian study reported increased worker mortality and queenlessness in colonies near corn fields treated with neonicotinoids (29). In another study (30), oral exposure to imidacloprid subtly affected honeybee motor function. Teeters et al. (31) recorded reduced flight envelope and interactions in their study using a video. In vitro research also confirmed adverse effects. In cultured Kenyon cells from the honeybee brain, imidacloprid and clothianidin at concentrations seen in foraging honeybees and hives caused a depolarisation block and inhibited nicotinic responses (32). Neonicotinoid exposure can also affect bee short-term memory and associative learning, as demonstrated by Zhang et al. (33). In another study (34), young adult honeybees exposed to imidacloprid both orally and topically showed changes in gustatory responsiveness and learning and memory impairment, which may negatively reflect on the bee hives. Significant adverse effects on learning performance were also established with a proboscis extension response (PER) assay in semi-field and laboratory conditions (35). The same study also found that syrup contaminated with imidacloprid decreased the foraging activity and the activity at the hive entrance. The forager return rate declined linearly with the increasing imidacloprid dose. El Hassani et al. (36), in turn, reported that acetamiprid increased antennal sensitivity to stimulation with sucrose solutions and impaired long-term retention of olfactory learning, whereas thoracic application induced no such effects but increased locomotor activity and waterinduced PER.

Most of these studies are focused on oral or thoracic topical exposure to neonicotinoids, but one study (37) through increased mortality showed that wings are another relevant route of exposure and proved that significant amounts of pesticides could be delivered to the wings by air displacement during flight.

A metabolic study (38) quantifying imidacloprid and its metabolites 5-hydroxyimidacloprid and olefin in honeybee concluded that imidacloprid was responsible for immediate neurotoxicity symptoms, whereas its metabolites must have been responsible for mortality, since it occurred post-ingestion at which time no imidacloprid was detected. However, neither of the two studied metabolites were involved, which suggests that other metabolites were responsible for the mortality. Zhu et al. (39) fed honeybees with a commercial formulation of imidacloprid in sucrose solution and noted higher cytochrome P450 activity. According to another study (40), honeybees mainly rely on cytochrome P450 monooxygenases to counter the toxic effects of this imidacloprid formulation, but other authors claim that every active substance is countered by different enzymes, at least in bumblebees (41).

Honeybees fed imidacloprid and clothianidin via foraging on conventionally grown maize showed elevated acetylcholinesterase (AChE) activity (42). Changes in honeybee thorax temperature might be linked to impaired foraging and in-hive performance, as Tosi et al. (43) found both significant increases and decreases in honeybee thorax temperatures, depending on environmental temperature. They also performed a cold shock experiment, where two higher doses elicited a decrease, and a lower dose an increase in thorax temperature. Histology revealed significant alterations across several tissues, and one of the most common findings was apoptosis. In another study (44) the TUNEL assay, immunofluorescence, and real-time polymerase chain reaction (RT-PCR) revealed increased neuronal apoptosis and apoptotic markers caspase- 3 and caspase-1 mRNA in honeybee brains, with concurrent autophagy. De Almeida Rossi et al. (45) treated honeybees with sublethal doses of imidacloprid and demonstrated cytotoxicity via Feulgen reaction, xylidine ponceau staining, and immunocytochemistry, with optic lobes being the most sensitive honeybee brain region to imidacloprid exposure. 
Oliveira et al. (46) also reported stronger xylidine ponceau staining in the optical lobes of bees exposed to thiametoxam compared to control, whereas the cells taken from the midgut showed morphological and histochemical changes. Catae et al. (47) established toxic effects of thiametoxam on malphigian tubules, with organ damage increasing with exposure duration. Similar cytotoxicity in malphigian tubules was established for sublethal imidacloprid (48). The suggested mechanism of toxicity in honeybees is the inhibition of mitochondrial activity and depletion of adenosine triphosphate (ATP) (49). In one study (50), bumblebees exposed to imidacloprid showed reduced ATP and visual impairment, indicating a toxicity mechanism in common with honeybees.

According to Wessler and Kirkpatrick (51), neonicotinoids and other neurotoxic pesticides might also affect the non-neuronal acetylcholine (ACh) system (a term referring to cells using paracrine secretion of $\mathrm{ACh}$ to communicate outside the cholinergic nervous system), which seems to play a role in honeybee reproduction. Their action can therefore impair reproduction and limit biodiversity. Straub et al. (52) studied sexual maturation of bee drones from hives exposed to clothianidin and thiametoxam and found lower sperm viability and count of living sperms, as well as shorter drone lifespan. Gajger et al. (53) studied the reproductive morphology of honeybee queens and found lower sperm count in the spermathecae that received the higher thiamethoxam dose. Chaimanee (54) reported lower sperm viability in queen honeybees exposed to imidacloprid.

Neonicotinoid exposure has also been shown to affect honeybee immunocompetence. For instance, Brandt et al. (15) have shown that exposure to field-realistic concentrations of thiacloprid and imidacloprid and to higher concentrations of clothianidin reduced haemocyte density, encapsulation response, and antimicrobial activity. In another study (55) clothianidin and imidacloprid induced immunosuppression via increased Nf-kB inhibition. In addition to honey production and total number of bees, imidacloprid significantly affected the activity of the immune-related enzyme phenoloxidase in forager bee extracts (56).

The effects of neonicotinoids on larval development have also been assessed. Tavares et al. $(57,58)$ reported lower larval and pupal survival and adult honeybee emergence for thiametoxam, as well as changes in acetylcholinesterase (AChE), glutathione-S-transferase (GST), carboxyesterase para, and alkaline phosphatase (ALP). In another study (59) newly emerged bees exposed to thiametoxam during the larval stage showed morphological changes suggestive of tissue degeneration in the digestive system, malphigian tubules, and Kenyon cells, likely to compromise their life span. Peng et al. (60) reported lower synaptic density in the calyx, which is responsible for the olfactory and visual functions, due to sublethal imidacloprid exposure of larvae. Yang et al. (61) studied the relation between larval imidacloprid exposure and delays in larval development stages and found no effect at sublethal concentrations. However, the associative olfactory behaviour of adult bees was significantly impaired.

At the genetic level, Wu et al. (62) reported a strong downregulation of the genes encoding major royal jelly proteins (MRJPs) in newly emerged adults exposed to imidacloprid as larvae. This group of proteins is important for the sustainable development of bee colonies. Two other studies $(63,64)$ reported that sublethal thiametoxam may target genes linked to many functions, including behaviour, immunity, metabolism, biosynthesis, translation, and neural function, whereas another study (65) found a drop in vitellogenin, an egg yolk precursor that regulates honeybee development and behaviour.

Laboratory and field studies disagree about the extent of neonicotinoid exposure effects. Honeybees exposed to imidacloprid in laboratory cages showed generalised immunosuppression and the triggering of detoxification enzymes, whereas field-treated bees were more resilient (66).

\section{Bumblebees}

Bumblebees are another important pollinator species. They seem to suffer the adverse insecticide effects even at concentrations regarded as safe (67). Studies of bumblebee exposure to insecticides consistently show greater sensitivity of these species compared to honeybees. The difference in sensitivity between honeybees and bumblebees was explained by better honeybee adaptation to feeding on nectars containing synthetic alkaloids such as neonicotinoids by virtue of their ancestral adaptation to tropical nectars in which natural alkaloids are prevalent (68). Bumblebees have been reported to retain higher levels of imidacloprid after ingestion than honeybees (69).

Like in honeybees, neonicotinoids seem to diminish the foraging ability and homing success of bumblebees (70). Laycock et al. (71) reported lower survival, brood size, and feeding in bumblebees exposed to thiametoxam applied at 39 and $88 \mu \mathrm{g} \mathrm{kg}^{-1}$ bw, but not at doses between 1 and $11 \mu \mathrm{g} \mathrm{kg}^{-1}$ bw as found in nectars. According to Bryden et al. (72), sublethal exposure leads to initial growth and then reduction in bumblebee colonies. However, different species of the Bombus genus are not equally sensitive to sublethal insecticide effects. Baron et al. (73) exposed wild queens of four bumblebee species [B. terrestris (Linnaeus), $B$. lucorum (Linnaeus), B. pascuorum (Scopoli), and $B$. pratorum (Linnaeus)] to thiametoxam and found reduced feeding in two species.

Neonicotinoids also affect the immune system of bumblebees. Imidacloprid lowered the activities of phenoloxidase and hemolymph and reduced bumblebee survival following non-pathogenic immune challenge (74).

As for the neurological effects, according to an in vitro study (75), imidacloprid and clothianidin can affect 
bumblebee behaviour by stimulating neural Kenyon cells In another study (76), bumblebees chronically exposed to field-realistic levels of thiametoxam learnt more slowly, and their short-term memory was significantly impaired. Experiments also show that successive generations of bumblebees adapt to imidacloprid exposure. In one study (77) neural cells of the newly emerged adult workers were less sensitive to imidacloprid exposure than the neural cells from older workers.

Different substances of the same class tend to have different effects on bumblebee cells, individuals, and whole colonies. In a study by Moffat et al. (75), imidacloprid and thiamethoxam, but not clothianidin, affected bumblebee colony strength, whereas thiametoxam was the only substance that affected the sex ratio (in favour of males).

Two studies even reported recovery from exposure to imidacloprid $(69,78)$. Acetamiprid has consistently been reported as the least toxic neonicotinoid. It first entered the European market following the approval by the European Food Safety Authority (EFSA) (79) due to its low non-target toxicity and low potential for bioaccumulation. Further studies supported its low toxicity to honeybees $(36,80,-81)$. Acetamiprid may owe its low toxicity to its chemical structure, which is different from older neonicotinoids such as imidacloprid. Acetamiprid is a cyano-substituted and imidacloprid a nitro-substituted compound (82). Furthermore, acetamiprid seems to be the least likely to enter a beehive (83).

Just as for honeybees, laboratory and field studies disagree about the extent of neonicotinoid exposure effects in bumblebees. Arce et al. (84) tried to bridge this disagreement by exposing bumblebees to controlled doses of clothianidin in sucrose syrup and by assessing their foraging activities and the number of workers and sexuals. The effect on foraging was small, but the number of bees dropped significantly.

Combined effects of neonicotinoids, parasites, and other stresses on pollinators

Since pollinators are rarely exposed to a single pesticide, many studies examined the combined effects of pesticides on non-target species. Liu et al. (85) exposed honeybees orally for $48 \mathrm{~h}$ to clothianidin, thiametoxam, and dinotefuran separately and in binary and ternary combinations. All combinations had additive or synergistic toxic effects.

Parasite infestations also seem to worsen the adverse effects of neonicotinoid pesticides, and the combination seems to be one of the main reasons for global pollinator decline $(86,87)$. In combination with infectious microspores, however, it increased short-term mortality and led to longterm colony decline (88). Imidacloprid exposure also reduced flight capacity of honeybees affected by the mite Varroa destructor (Anderson \& Trueman) (89). In an observational study in the Netherlands, $V$. destructor mite infestation and the presence of acetamiprid and thiacloprid were the two most significant factors in winter honeybee losses (90). Sublethal doses of thiacloprid caused higher mortality in honeybees infected with Nosema ceranae (Fries) than in the uninfected ones (91). Field-realistic nutritional stress and pesticide exposure were also reported to synergistically diminish honeybee survival (92). All these findings point to a greater susceptibility to pathogens in neonicotinoid-exposed pollinators (93).

Another stressor contributing to bee population decline is poor diet, whose effects are even worse if combined with a neonicotinoid, as reported by Dance et al. (94) for bumblebees feeding on monofloral pollen coated with thiametoxam.

\section{Non-target toxicity of neonicotinoids in other insects and invertebrates}

Apis cerana (Fabricius) is another aphid species prevalent in Asia. Because of its smaller mass, it would be reasonable to assume that this species is more sensitive to neonicotinoids than Apis mellifera (Linnaeus), but Yue et al. (95) reported that both species were equally sensitive to dinotefuran, A. cerana (Fabricius) was more sensitive to acetamiprid, and $A$. mellifera (Linnaeus) was more sensitive to imidacloprid and thiametoxam. One study with a stingless bee species Osmia cornuta (Latreille) found impaired visual guidance and navigational memory caused by clothianidin (96). Whitehorn et al. (97) found an interesting effect of imidacloprid on Nasonia vitripennis, as it produced more females in the offspring than control. Studying ants, Thiel et al. (98) noted delays in the recruitment of new workers in the Lasius niger (Linnaeus) species and fewer foragers and greater aggression in the L. flavus species. Another and study found lower interspecies aggression and higher survival in a native species and higher interspecies aggression and lower survival in the invasive species, both exposed to imidacloprid (99).

Trophic transfer has been proposed as an important route of entry for neonicotinoids into the ecosystem, as thiametoxam from treated soybean travelled through herbivorous slug species into a predatory arthropod in the amounts sufficient to reduce its population density (100). This is another, albeit under-researched way insecticides can harm beneficial insects and disrupt biological pest control.

Cavallaro et al. (101) reported lower toxicity of thiametoxam in Chironomus dilutus than that of imidacloprid and clothianidin yet it does not make it environmentally less dangerous, as it quite likely degrades into clothianidin in the environment.

In Chironomus riparium (Meigen) low concentrations of thiametoxam inhibited growth, catalase activity, and caused lipid peroxidation (102). Azevedo-Pereira et al. (103) reported an imidacloprid-related drop in AChE activity, which correlated with reduced locomotion and ventilation in the same species. 
Kobashi et al. (104) tested the survival of several aquatic insect species exposed to imidacloprid and dinotefuran and noted that it dropped in C. servilia mariannae (Drury), $L$. pachygastra (Selys), N. triguttata, and G. japonicus exposed to imidacloprid, but not to dinotefuran.

Malev et al. (105) exposed a crustacean amphipod Gammarus fossarum (Koch) and freshwater algae Desmodesmus subspicatus (Chodat) to imidacloprid active substance, its commercial formulation, and to its metabolite, 6-chloronicotinic acid and found reduced algal growth and elevated catalase activity and lipid peroxidation. Ugurlu et al. (106) found vacuolisation and haemostatic infiltration in the gill cells of Gammarus kischineffensis (Schellenberg) exposed to sublethal concentrations of thiametoxam.

Arican et al. (107) found reduced feeding in copepods exposed to thiacloprid and proposed feeding response as a more sensitive endpoint for ecological risk assessment than acute or chronic toxicity.

Imidacloprid was also shown to be toxic to earthworm Eisenia fetida (Savigny) $(108,109)$ and Hyalella azteca (Saussure) (110). Eisenia andrei (Bouché) showed bioaccumulation of various pesticides, which correlated with DNA damage (111). Van Hoesel et al. (112) also found reduced surface activity of earthworms in pots with wheat treated by seed dressing formulation based on imidacloprid and a fungicide prothioconazole.

\section{Neonicotinoid effects on vertebrates}

Early developmental exposure to imidacloprid has persisting effects on neurobehavioral function in zebrafish (113). Both active imidacloprid and its commercial formulation accumulated in the gut, gills, liver, and muscles of Australoherus facetus (Jenyns) and had genotoxic effects (114). Ansoar-Rodriguez et al. (115) found histopathological changes and increased levels of heat-shock-protein (Hsp) 70, pointing to hepatotoxicity in Oreochromic niloticus (Linneaus). Xia et al. (116) reported genotoxicity, a decrease in hepatic enzymes glutamic-pyruvic transaminase and glutamic-oxalacetic transaminase, and histological changes in the testes of adult pond loach [Misgurnus anguilicaudatus, (Cantor)] exposed to sublethal concentrations of imidacloprid.

Imidacloprid exposure of chick embryos could increase the risk of neural tube defects and dysplasia (117). LopezAntia et al. (118) exposed Alectoris rufa partridges (Linnaeus) to imidacloprid-coated seeds and found increased mortality at recommended application concentrations, reduction in clutch sizes and egg laying delays, as well as reduced T-cell immune response. Imidacloprid was also reported to impact bobwhite quail [Colinus virginianus (Linnaeus)] embryonic development and chick survival, but this depended on specific exposure windows (119). Developmental delay was also noted in chick embryos $(120,121)$ exposed to imidacloprid, as well as histological changes in the chick cerebellum (122).
Male C57BL/6N mice exposed to a single dose of noobserved-adverse-effect level (NOAEL) of clothiadin showed elevated anxiety and increase in c-fos immunoreactivity in certain brain regions (123). Imidacloprid was also reported to stimulate high-fat-dietinduced adiposity and insulin resistance in mice (124). Male mice exposed to $1 \mathrm{mg} \mathrm{kg}^{-1} \mathrm{bw}$ of imidacloprid in utero and during lactation showed elevated aggressive and sexual behaviour, suggesting male-specific impairment of neural development (125). Exposure of gestating mice to clothianidin also reduced germ cell count in the offspring without hormonal changes (126). Still in mice, Hirano et al. (127) reported clothianidin-induced behavioural and reproductive effects, which were more pronounced under chronic stress. Treatment of mouse embryos with $1000 \mu \mathrm{mol} \mathrm{L}-1$ of thimaetoxam, clothianidin, acetamiprid, and thiacloprid during the preimplantation period had negative effects on embryo developmental abilities (128). Exposure to imidacloprid at concentrations higher than $10 \mu \mathrm{mol} \mathrm{L}^{-1}$ for less than one minute changed the membrane properties of mouse stellate cells with AChRs (from the cochlear nucleus) and consequently their function (129). Ten-week-old mice drinking water spiked with acetamiprid at ten and hundred times the NOAEL had the substance concentrated in the midbrain region, and their body weight decreased (130).

In rats, high doses of acetamiprid reduced liver weight and changed haematological parameters and liver ALT, AST, ALP, and LDH activities (131). Rats exposed to high doses of thiametoxam for seven days showed increased anxiety and a drop in AChE activity, which points to the affected cholinergic system (132). $10 \mathrm{mmol} \mathrm{L}^{-1}$ of thiametoxam and $2 \mathrm{mmol} \mathrm{L}^{-1}$ of clothianidin increased extracellular dopamine levels when injected into the rat brain striatum, further characterising its mode of action in mammalian brain (133). Commercial thiacloprid, alone and in combination with deltamethrin, elevated free T3 and T4 hormone levels in rat serum in both single-dose and 30-day exposure (134). Subchronic (110 $\left.\mathrm{mg} \mathrm{kg}^{-1} \mathrm{bw}\right)$ administration of acetamiprid significantly decreased lymphocyte proliferation and macrophage function (135). Exposure to high doses of clothianidin (24 mg kg-1 bw) affected the cognitive function of infant Wistar rats (136). At low doses clothianidin moderately affected the reproductive system of male rats exposed in utero (137). In contrast, a daily three-month exposure to imidacloprid ( $8 \mathrm{mg} \mathrm{kg}^{-1} \mathrm{bw}$ ) significantly impaired the testicular function of adult male rats (138).

Hsiao et al. (139) reported impaired spatial memory in bats after chronic exposure to imidacloprid. They explained it with neuronal apoptosis in their brain.

Finally, dogs also seem to be affected by neonicotinoids. An epidemiological study by Gookin et al. (140) established an association between imidacloprid exposure and gallbladder mucocele formation, with the risk even higher in Shetland sheepdogs. 


\section{Human exposure to neonicotinoids}

An observational study (141) noted a potential link between maternal exposure to agricultural pesticides such as neonicotinoids and pyrethroids and poorer neurodevelopment in children. A slight correlation between maternal exposure and autism spectrum disorder in children has also been reported by Keil et al. (142). According to a longitudinal study based on Texan poison centre reports, adverse events in people exposed to neonicotinoids were not severe and most of them were managed outside medical facilities (143).

\section{Pyrethroids}

Pyrethrins are naturally occurring compounds obtained by extraction from pyrethrum [Chrysanthemum cinerariaefolium (Linnaeus)]. They have insecticidal properties but are unstable when exposed to sunlight. Research into modifications of their structure has led to the development of synthetic pyrethroids with greater stability and insecticidal activity (19). These include cypermethrin, cyhalothrin, permethrin, bifenthrin, (es)fenvalerate, and cyfluthrin. Their mechanisms of action involve binding to voltage-gated sodium channels in insect neurons, preventing repolarisation, and inducing paralysis. Based on their structure, differences in specific electrophysiological effects, and poisoning syndromes in rats, they have been divided into type I and type II pyrethroids; the former causes aggressive behaviour, ataxia, convulsions, and progressive paralysis, whereas the latter causes choreoathetosis, salivation, and tremors (144).

Many of these substances have chiral carbon atoms that create enantiomers with identical physicochemical properties but different biological effects because of the binding stereoselectivity to receptors and other macromolecules within biological systems. This tends to complicate matters regarding their toxicology (145). Many studies treat different enantiomers in the racemic mixture as a single compound (146), yet their behaviour may differ. Yang and Ji (147) reported different degradation rates of the four beta-cypermethrin isomers they studied in soil. Likewise, enantiomers can differ in toxicokinetics. De Albuquerque et al. (148) reported that rat liver microsomes metabolised the (-)(1S-cis- $\alpha \mathrm{R})$ diastereoisomer of $\alpha$-cypermethrin faster than the $(+)(1 \mathrm{R}$-cis- $\alpha \mathrm{S})$ diastereoisomer. They concluded that the stereoselective effects of chiral pesticides should be evaluated both in the environment and non-target species. Stereoselectivity was also demonstrated with DDT and cancer progression in MCF-7 cells (149). Chang et al. (150) reported different bioaccumulation effects on the thyroid hormone of two lambda-cyhalothrin enantiomers. Stereoselective toxicokinetics has also been reported for cycloxaprid in rats (151). All these reports show that it is very important to specify whether a racemate (such as cypermethrin), an enriched enantiomer mixture (such as alpha-cypermethrin), or a pure enantiomer substance was used in toxicity studies.

\section{Pyrethroid effects on non-target insects and invertebrates}

Similar to neonicotinoids, pyrethroids have also been suspected to cause honeybee population declines. In one study (35) deltamethrin was lethal to worker bees and reduced their foraging activity at food source and hive entrance activity. In another study (152), cypermethrin inhibited $\mathrm{Na} / \mathrm{K}$ ATPase in emerging honeybees in laboratory conditions. In caged honeybees it altered the expression of the genes involved in the immune system, cytochrome P450 enzymes, subunits of nAChRs, and vitellogenin (153).

Evidence of adverse effects abounds for other insects as well. Kunce et al. (154) exposed damselfly larvae to deltamethrin and esfenvalerate and found reduced predatory ability with deltamethrin and GST inhibition with combined exposure. No effect of exposure to lambda cyhalothrin through biofilm on mayfly mortality has been reported, unlike direct exposure of mayflies through insecticidespiked water (155). In yet another study (156), deltamethrin, lambda-cyhalothrin, and esfenvalerate were more toxic to Iphiseiodes zugalai (Denmark \& Muma) larvae and adult mites than neonicotinoids imidacloprid and thiametoxam in terms of mortality, maturation, fecundity, longevity, and duration of adverse effects. Some insect species differ in sensitivity to pyrethroid exposure, as of the two predatory insects exposed to deltamethrin, Buenoa tarsalis (Truxal) was more sensitive than Martarega Bentoi (Truxal). (157)

In crustaceans, interactions between several pyrethroids tend to produce additive toxic effects, but some interactions were antagonistic, as reported for $H$. azteca (158). Alphacypermethrin showed adverse effects on Daphnia magna (Straus) adult growth and neonate size and number (159).

A combination of permethrin, lambda-cyhalothrin, and chlorpyrifos induced response in 12 of 15 zooplankton species, with the most sensitive species being the Radix sp. snail, H. azteca, D. magna, and copepods. H. Azteca and D. magna showed acute toxicity, and the snails and copepods a delayed sublethal response (160). One study (161) reported the prevalence of permethrin and cypermethrin in urban river sediment in South China, whose levels were toxic to $C$. dilutus.

\section{Pyrethroid effects on non-target vertebrates}

Pyrethroids have been shown to exert endocrine disruption in fish. In embryonic zebrafish, permethrin increased thyroxine and 3,5,3'-triiodothyronine levels and the transcription of most target genes involved in the hypothalamic-pituitary-thyroid axis (162). Simultaneous exposure to other insecticides can exacerbate symptoms of toxicity. Fai et al. (163) reported that $O$. niloticus was more sensitive to cypermethrin and deltamethrin than the organophosphate (OP) pesticide dimethoate, but together 
the three showed synergistic toxicity, possibly due to OP inhibition of the pyrethroid-hydrolysing esterases.

In toads, deltamethrin caused oxidative stress, affecting the catalase, glutathione reductase, and GST activities in different tissues (164).

Mice fed with formulated cypermethrin for 60 days exhibited chromosome aberrations, micronuclei, reactive oxygen species, and disturbed cell cycle (165). Bardullas et al. (166) noted hypothermia in infant rats exposed to low doses of cypermethrin and bifenthrin, along with mild to moderate behavioural effects. Gamma-cyhalothrin, an enriched mixture of cyhalothrin isomers, was more neurotoxic to rats than lambda-cyhalothrin (167). Still in rats, a low-dose permethrin induced changes in liver histology, increase in lipid peroxidation, and a drop in superoxide dismutase activity in one study (168) and was responsible for altered Nurrl gene expression and reduced genome-wide DNA methylation in the offspring of pregnant rats in another (169). Upregulation of Nurrl was later associated with lower antioxidant concentrations (170). Pregnant dams treated with $10 \mathrm{mg} \mathrm{kg}^{-1} \mathrm{bw}$ of deltamethrin showed transient neurotoxicity and weight loss, but no effect on testosterone synthesis was observed in their male offspring (171). Beta-cyfluthrin and bifenthrin affected behaviour in adult and neonate rats, which may be related to a drop in AChE activity and the elevated oxidative stress in their brains (172). Another study also showed that the blood-brain barrier of infant rats was more permeable to deltamethrin than that of older rats (173). Allethrin, one of the first pyrethroids, decreased spermatogenesis and sperm function in male rats by downregulating the mRNA expression of factors important for testosterone levels, sperm count, and sperm function (174).

In mice, pulsed exposure to low-dose $\left(3 \mathrm{mg} \mathrm{kg}^{-1} \mathrm{bw}\right)$ deltamethrin during gestation and lactation showed regionspecific downregulation of Na-v mRNA and brain-derived neurotrophic factor, suggesting a mechanism for behavioural effects (175). Fenvalerate, known as endocrine disruptor from other studies, restricted intrauterine growth by disrupting placental thyroid hormone receptor signalling (176). In another study (177) cypermethrin applied at environmentally relevant doses to male mice significantly accelerated the onset of puberty by interfering with the hypothalamic sodium channels, pituitary gonadotrope calcium channels, and testicular Leydig cells, which all led to higher FSH, LH, and testosterone levels.

Exposure of male rabbits to two doses of cypermethrin for two and four months led to increased genotoxicity in the lymphocytes and cytotoxicity in the liver and kidney, as demonstrated by the cytokinesis-block micronucleus assay and histological examination (178).

\section{Human exposure to pyrethroids}

Many studies have assessed the links between residential and occupational exposure to pyrethroids and potential health effects. Vidi et al. (179) reported a significant association between bifenthrin, cypermethrin, deltamethrin, cis- and trans-permethrin and DNA damage in the hair of residentially exposed children in farmer households. An observational study using data from poison control centres reported that the second most common pesticide group by exposure frequency were pyrethroids, and children aged $\leq 5$ years were the group most at risk of exposure (180). Campos et al. (181) suggested an association between pyrethroid exposure and mental disorders. Poorer neurodevelopment in children in relation to maternal exposure to pyrethroids was further demonstrated by Gunier et al. (141). Furlong et al. (182) found a correlation between the levels of pyrethroid urinary metabolites 3-PBA and DCCA and behavioural deficits in children. Another study reported a stronger link between indoor pyrethroid exposure and autism spectrum disorder in the children of mothers who received less folic acid during pregnancy than those who received more (183). In a cross-sectional study of female farm workers in Tanzania, occupational exposure to pesticides affected haematological and biochemical parameters such as haematocrit, red cell corpuscular volume, serum glutamic oxaloacetate transaminase, and esterase (184). One case of pyrethroid skin necrosis was reported in a 67-year old diabetic woman suffering from delusions of parasitosis (185). In a recent review Martenies et al. (186) identified four studies showing an association between urinary metabolites of pyrethroids and lower semen concentration. Chiu et al. (187), however, reported the opposite: consumption of fruit and vegetables with low-to-moderate pesticide residues was associated with improved total sperm count and sperm concentration. The authors suggested that pesticide residues in fruit and vegetables could offset the beneficial effects of antioxidants and other naturally occurring chemicals in human organism. So far, however, there are too few studies of this type to infer anything more than that an association may exist. Similar to the finding in mice above (177), an observational study reported a positive correlation between pyrethroid urinary metabolites 3-PBA and 4-F-3PBA and gonadotropin levels (FSH and LH) and early-onset puberty in Chinese boys (188).

\section{NEEM-BASED INSECTICIDES}

Unlike the previous two groups of naturally occurring insecticides, little is known about the non-target toxicity of neem-based insecticides. What literature there is, it mainly reports no adverse environmental effects. However, one study reported azadirachtin suppression of otherwise beneficial phosphate-solubilising bacteria in soil (189). In another study, neem-based formulations changed the composition of zooplanktonic communities at higher concentrations (190). In adult copepods, azadirachtin reduced their population (191), which was also noted in 
another study with adult copepods in pond enclosures (192). This adversely affects zooplankton food web stability. Similar perturbations in planktonic communities were also noted by Kreutzweiser et al. (193). Goktepe and Plhak (194) confirmed direct adverse effects on aquatic organisms with azadirachtin formulations more resistant to degradation by sunlight.

Regarding non-target insect effects, exposure of bumblebees to azadirachtin caused a variety of toxic effects, including reduced offspring mass, absence of reproduction, and mortality (195). Neem oil affected cocoon spinning in Ceraeochrysa claveri (Navás), possibly increasing their vulnerability to natural enemies and environmental factors (196).

There are several reports of neem-based compounds affecting fish. Intramuscular application of low-dose azadirachtin in Oreochromis Mossambicus (Peters) caused chromosomal aberrations (197). In carp it significantly altered locomotor and haematological parameters (198). In catfish it affected leukocyte populations, which pointed to a possible immunotoxicity (199). Azadirachtin also caused histological changes to ultimobrachial gland, an organ important for calcium homeostasis, in the Asian stinging catfish [Heteropneustes fossilis (Bloch)], but only with prolonged exposure (200). In zebrafish, it increased general activity and anxiety-like symptoms, but there was no effect on learning (201).

As for mammals, neem extract seems to be spermatotoxic in rats (202). In another study (203) high concentrations of azadirachtin reversibly affected rat neuron excitability by modulating potassium conductances. Vepacide, a neem oil-based preparation, increased aspartate and alanine aminotransferase in the serum, kidney, and lung, but decreased them in the liver of rats, suggesting liver necrosis (204). Subchronic exposure of Wistar rats to vepacide induced biochemical changes in the levels of acid and alkaline phosphatase (205). In contrast, azadirachtin showed no signs of toxicity in either gestational rats or their offspring (206), or in subchronically treated adult rats of either sex (207).

Little is still known about the risks for humans. What we know is that azadirachtin has no genotoxic effect on human cells, but may have antiproliferative effects, as evidenced by the changes in the cell cycle of human lymphocytes, some of which also displayed aberrant mitoses and poliploidy with multipolar spindles (208). One study reported that an azadirachtin-based nematicide caused eye irritation but no systemic effects (209). There is also a case report of a 35-year-old woman showing transient signs of neurotoxicity after ingesting azadirachtin in a suicide attempt (210).

\section{CONCLUSIONS}

Experimental evidence suggests diverse toxicities of the three new, presumably selective and environmentally safe insecticides in non-target, environmentally beneficial insects, planktonic organisms, fish, and mammals. With pyrethroids this is in no small part due to their stereoselectivity. Although an increasing number of studies now acknowledges stereoselectivity as an important factor in toxicological assessment, more research is needed on this subject.

The reviewed studies have also shown that insecticides when mixed, which corresponds to real-life exposure patterns, mostly interact to produce additive or synergistic effects, but antagonisms have also been noted. Further research should investigate the mechanisms of these interactions on the molecular level.

Many practical measures can be put to use to buffer the negative impacts of pesticides on the environment, such as rotating different insecticides (39), combining common insecticides with detoxification-enzyme-inducing pesticides (40), and avoiding pesticides affecting beneficial predatory arthropods used in biological pest control. The risk to pollinators and other non-target organisms may also be reduced by aligning the use of insecticides with pest incidence (211). Furthermore, treating certain species such as bumblebees with near infrared light seems a promising way to counter imidacloprid effects (50).

Promising improvements also come with even newer alternative insecticides, such as a spider-venom derivative atracotoxin that targets calcium channels. In an early-tier risk assessment (212) it did not affect honeybee mortality or learning, nor was it toxic to larvae. Of course, full risk assessment should involve the whole lifecycle of colony health and include other species and interactions with other stressors such as pathogens.

Regarding neem-based pesticides, further research into the effects on beneficial pollinator species is needed to complement its relatively favourable toxicological profile in mammals.

\section{Conflict of interest}

None to declare.

\section{Acknowledgements}

This work was financially supported by Project Organic Pollutants in Environment - Markers and Biomarkers of Toxicity (OPENTOX), funded by the Croatian Science Foundation (grant number 8366).

\section{REFERENCES}

1. Oberemok VV, Laikova KV, Gninenko YI, Zaitsev AS, Nyadar PM, Adeyemi TA. A short history of insecticides. J Plant Prot Res 2015;55:221-6. doi: 10.1515/jppr-2015-0033 
2. Amweg EL, Weston DP, Ureda NM. Use and toxicity of pyrethroid pesticides in the Central Valley, California, USA. Environ Toxicol Chem 2005;24:966-72. doi: 10.1897/04146R1.1

3. Simon-Delso N, Amaral-Rogers V, Belzunces LP, Bonmatin JM, Chagnon M, Downs C, Furlan L, Gibbons DW, Giorio C, Girolami V, Goulson D, Kreutzweiser DP, Krupke CH, Liess M, Long E, McField M, Mineau P, Mitchell EA, Morrissey CA, Noome DA, Pisa L, Settele J, Stark JD, Tapparo A, Van Dyck H, Van Praagh J, Van der Sluijs JP, Whitehorn PR, Wiemers M. Systemic insecticides (neonicotinoids and fipronil): trends, uses, mode of action and metabolites. Environ Sci Pollut R 2015;22:5-34. doi: 10.1007/s11356-014-3470-y

4. Dryden MW, Rust MK. The cat flea - biology, ecology and control. Vet Parasitol 1994;52:1-19. doi: 10.1016/03044017(94)90031-0

5. Marsh RE. Vertebrate pest control chemicals and their use in urban and rural environments. In: Keirger R, editor. Handbook of Pesticide Toxicology. $2^{\text {nd }}$ ed. San Diego (CA) Academic Press; 2001. p. 251-62. doi: 10.1016/B978012426260-7.50010-0

6. Roberts DR, Andre RG. Insecticide resistance issues in vector-borne disease-control. Am J Trop Med Hyg 1994;50:21-34

7. Costa LG.Toxic effects of pesticides. In: Klaassen CD, editor. Casarett and Doull's Toxicology: The Basic Science of Poisons. $8^{\text {th }}$ ed. New York (NY): McGraw-Hill Education; 2013. p. 983-91.

8. Stratonovitch P, Elias J, Denholm I, Slater R, Semenov MA. An individual-based model of the evolution of pesticide resistance in heterogenous environments: control of Meligethes aeneus population in oilseed rape crops. PLoS One 2014;9:e115631. doi: 10.1371/journal.pone.0115631

9. Phillips BM, Anderson BS, Voorhees JP, Siegler K, Denton D, TenBrook P, Larsen K, Isorena P, Tjeerdema RS Monitoring the aquatic toxicity of mosquito vector control spray pesticides to freshwater receiving waters. Integr Environ Asses 2014;10:449-55. doi: 10.1002/ieam.1534

10. Suratman S, Edwards JW, Babina K. Organophosphate pesticides exposure among farmworkers: pathways and risk of adverse health effects. Rev Environ Health 2015;30:65-79. doi: 10.1515/reveh-2014-0072

11. Hawkins TR. Re-reading Silent Spring. Environ Health Persp 1994;102:536-7. PMCID: PMC1569756

12. Kabasenche WP, Skinner MK. DDT, epigenetic harm and transgenerational environmental justice. Environ Health 2014;13:62. doi: 10.1186/1476-069X-13-62

13. Agricultural Sustainability Institute (ASI). What is sustainable agriculture? [displayed 6 February 2018] Available at http://asi.ucdavis.edu/programs/sarep/about/ what-is-sustainable-agriculture/\#concept-themes

14. Casida JE. The greening of pesticide-environment interactions: some personal observations. Environ Health Persp 2012;120:487-93. doi: 10.1289/ehp.1104405

15. Brandt A, Gorenflo A, Siede R, Meixner M, Büchler R. The neonicotinoids thiacloprid, imidacloprid, and clothianidin affect the immunocompetence of honeybees (Apis mellifera L.). J Insect Physiol 2016;86:40-7. doi: 10.1016/j. jinsphys.2016.01.001

16. Tison L, Hahn ML, Holtz S, Rossner A, Greggers U, Bischoff G, Menzel R. Honeybees' behavior is impaired by chronic exposure to the neonicotinoid thiacloprid in the field. Environ Sci Technol 2016;50:7218-27. doi: 10.1021/acs.est.6b02658

17. Deng YX, Cao M, Shi DX, Yin ZQ, Jia RY, Xu J, Wang C, Lv C, Liang XX, He CL, Yang ZR, Zhao J. Toxicological evaluation of neem (Azadirachta indica) oil: Acute and subacute toxicity. Environ Toxicol Phar 2013;35:240-6. doi: 10.1016/j.etap.2012.12.015

18. Adel MM, Sehnal F. Azadirachtin potentiates the action of ecdysteroid agonist RH-2485 in Spodoptera littoralis. J Insect Physiol 2000;46:267-74. doi: 10.1016/S0022-1910(99)00179-1

19. Lopez O, Fernandez-Bolanos JG, Gil MV. New trends in pest control: the search for greener insecticides. Green Chem 2005;7:431-42. doi: 10.1039/B500733J

20. Stokstad E. Agriculture. Field research on bees raises concern about low-dose pesticides. Science 2012;335:1555. doi: 10.1126/science.335.6076.1555

21. Fairbrother A, Purdy J, Anderson T, Fell R. Risks of neonicotinoid insecticides to honeybees. Environ Toxicol Chem 2014;33:719-31. doi: 10.1002/etc. 2527

22. Samson-Robert O, Labrie G, Chagnon M, Fournier V. Neonicotinoid-contaminated puddles of water represent a risk of intoxication for honeybees. PLoS One 2014;9:e0119357. doi: 10.1371/journal.pone.0108443

23. Sadaria AM, Supowit SD, Halden RU. Mass balance assessment for six neonicotinoid insecticides during conventional wastewater and wetland treatment: nationwide reconnaissance in United States wastewater. Environ Sci Technol 2016;50:6199-206. doi: 10.1021/acs.est.6b01032

24. Tapparo A, Marton D, Giorio C, Zanella A, Solda A, Marzano M, Vivan L, Girolami V. Assessment of the environmental exposure of honeybees to particulate matter containing neonicotinoid insecticides coming from corn coated seeds. Environ Sci Technol 2012;46:2592-9. doi: 10.1021/ es2035152

25. Biddinger DJ, Robertson JL, Mullin C, Frazier J, Ashcraft SA, Rajotte EG, Joshi NK, Vaughn M. Comparative toxicities and synergism of apple orchard pesticides to Apis mellifera (L.) and Osmia cornifrons (Radoszkowski). PLoS One 2013;8:e72587. doi: 10.1371/journal.pone.0072587

26. Yang EC, Chuang YC, Chen YL, Chang LH. Abnormal foraging behavior induced by sublethal dosage of imidacloprid in the honeybee (Hymenoptera: Apidae). J Econ Entomol 2008;101:1743-8. doi: 10.1603/0022-0493-101.6.1743

27. Cresswell JE. A meta-analysis of experiments testing the effects of a neonicotinoid insecticide (imidacloprid) on honeybees. Ecotoxicology 2011;20:149-57. doi: 10.1007/ s10646-010-0566-0

28. Dively GP, Embrey MS, Kamel A, Hawthorne DJ, Pettis JS. Assessment of chronic sublethal effects of imidacloprid on honeybee colony health. PLoS One 2015;10:e0118748. doi: 10.1371/journal.pone. 0118748

29. Tsvetkov N, Samson-Robert O, Sood K, Patel HS, Malena DA, Gajiwala PH, Maciukiewicz P, Fournier V, Zayed A. Chronic exposure to neonicotinoids reduces honeybee health near corn crops. Science 2017;356:1395-7. doi: 10.1126/ science.aam 7470

30. Williamson SM, Willis SJ, Wright GA. Exposure to neonicotinoids influences the motor function of adult worker honeybees. Ecotoxicology 2014;23:1409-18. doi: 10.1007/ s10646-014-1283-x

31. Teeters BS, Johnson RM, Ellis MD, Siegfried BD. Using video-tracking to assess sublethal effects of pesticides on 
honeybees (Apis mellifera L.). Environ Toxicol Chem 2012;31:1349-54. doi: 10.1002/etc. 1830

32. Palmer MJ, Moffat C, Saranzewa N, Harvey J, Wright GA, Connolly CN. Cholinergic pesticides cause mushroom body neuronal inactivation in honeybees. Nat Commun 2013;4:1634. doi: $10.1038 /$ ncomms 2648

33. Zhang E, Nieh JC. The neonicotinoid imidacloprid impairs honeybee aversive learning of simulated predation. J Exp Biol 2015;218:3199-205. doi: 10.1242/jeb.127472

34. Mengoni Goñalons C, Farina WM. Effects of sublethal doses of imidacloprid on young adult honeybee behaviour. PLoS One 2015;10:e0140814. doi: 10.1371/journal.pone.0140814

35. Decourtye A, Devillers J, Cluzeau S, Charreton M, PhamDelègue $\mathrm{MH}$. Effects of imidacloprid and deltamethrin on associative learning in honeybees under semi-field and laboratory conditions. Ecotox Environ Safe 2004;57:410-9. doi: 10.1016/j.ecoenv.2003.08.001

36. El Hassani AK, Dacher M, Gary V, Lambin M, Gauthier M, Armengaud C. Effects of sublethal doses of acetamiprid and thiamethoxam on the behavior of the honeybee (Apis mellifera). Arch Environ Con Tox 2008;54:653-61. doi: 10.1007/s00244-007-9071-8

37. Poquet Y, Kairo G, Tchamitchian S, Brunet JL, Belzunces LP. Wings as a new route of exposure to pesticides in the honeybee. Environ Toxicol Chem 2015;34:1983-8. doi: 10.1002/etc. 3014

38. Suchail S, Debrauwer L, Belzunces LP. Metabolism of imidacloprid in Apis mellifera. Pest Manag Sci 2004;60:2916. doi: $10.1002 /$ ps. 772

39. Zhu YC, Yao J, Adamczyk J, Luttrell R. Feeding toxicity and impact of imidacloprid formulation and mixtures with six representative pesticides at residue concentrations on honeybee physiology (Apis mellifera). PLoS One 2017;12:e0178421. doi: 10.1371/journal.pone.0178421

40. Zhu YC, Yao J, Adamczyk J, Luttrell R. Synergistic toxicity and physiological impact of imidacloprid alone and binary mixtures with seven representative pesticides on honeybee (Apis mellifera). PLoS One 2017;12:e0176837. doi: 10.1371/ journal.pone. 0176837

41. Raimets R, Karise R, Mänd M, Kaart T, Ponting S, Song J, Cresswell JE. Synergistic interactions between a variety of insecticides and an ergosterol biosynthesis inhibitor fungicide in dietary exposures of bumble bees (Bombus terrestris L.). Pest Manag Sci 2017;74:541-6. doi: 10.1002/ps.4756

42. Boily M, Sarrasin B, DeBlois C, Aras P, Chagnon M. Acetylcholinesterase in honeybees (Apis mellifera) exposed to neonicotinoids, atrazine and glyphosate: laboratory and field experiments. Environ Sci Pollut R 2013;20:5603-14. doi: 10.1007/s11356-013-1568-2

43. Tosi S, Démares FJ, Nicolson SW, Medrzycki P, Pirk CW, Human H. Effects of a neonicotinoid pesticide on thermoregulation of African honeybees (Apis mellifera scutellata). J Insect Physiol 2016;93-94:56-63. doi: 10.1016/j.jinsphys.2016.08.010

44. Wu YY, Zhou T, Wang Q, Dai PL, Xu SF, Jia HR, Wang X. Programmed cell death in the honeybee (Apis mellifera) (Hymenoptera: Apidae) worker brain induced by imidacloprid. J Econ Entomol 2015;108:1486-94. doi: 10.1093/jee/tov146

45. De Almeida Rossi, C, Roat, TC, Tavares, DA, CintraSocolowski, P, Malaspina, O. Brain morphophysiology of Africanized bee Apis mellifera exposed to sublethal doses of imidacloprid. Arch Environ Con Tox 2013;65;234-43. doi: 10.1007/s00244-013-9897-1

46. Oliveira RA, Roat TC, Carvalho SM, Malaspina O. Sideeffects of thiamethoxam on the brain andmidgut of the africanized honeybee Apis mellifera (Hymenoptera: Apidae). Environ Toxicol 2014;29:1122-33. doi: 10.1002/tox.21842

47. Catae AF, Roat TC, De Oliveira RA, Nocelli RC, Malaspina O. Cytotoxic effects of thiamethoxam in the midgut and malpighian tubules of Africanized Apis mellifera (Hymenoptera: Apidae). Microsc Res Techniq 2014;77:27481. doi: $10.1002 /$ jemt. 22339

48. De Almeida Rossi C, Roat TC, Tavares DA, CintraSocolowski P, Malaspina O. Effects of sublethal doses of imidacloprid in Malpighian tubules of Africanized Apis mellifera (Hymenoptera, Apidae). Microsc Res Techniq 2013;76:552-8. doi: 10.1002/jemt.22199

49. Nicodemo D, Maioli MA, Medeiros HC, Guelfi M, Balieira KV, De Jong D, Mingatto FE. Fipronil and imidacloprid reduce honeybee mitochondrial activity. Environ Toxicol Chem 2014;33:2070-5. doi: 10.1002/etc.2655

50. Powner MB, Salt TE, Hogg C, Jeffery G. Improving mitochondrial function protects bumblebees from neonicotinoid pesticides. PLoS One 2016;11:e0166531. doi: 10.1371/journal.pone.0166531

51. Wessler IK, Kirkpatrick CJ. Non-neuronal acetylcholine involved in reproduction in mammals and honeybees. J Neurochem 2017;142(Suppl 2):144-50. doi: 10.1111/ jnc. 13953

52. Straub L, Villamar-Bouza L, Bruckner S, Chantawannakul P, Gauthier L, Khongphinitbunjong K, Retschnig G, Troxler A, Vidondo B, Neumann P, Williams GR. Neonicotinoid insecticides can serve as inadvertent insect contraceptives. Proc Roy Soc B Biol Sci 2016;283:20160506. doi: 10.1098/ rspb.2016.0506

53. Gajger IT, Sakač M, Gregorc A. Impact of thiamethoxam on honeybee queen (Apis mellifera carnica) reproductive morphology and physiology. B Environ Contam Tox 2017;99:297-02.

54. Chaimanee V, Evans JD, Chen Y, Jackson C, Pettis JS. Sperm viability and gene expression in honeybee queens (Apis mellifera) following exposure to the neonicotinoid insecticide imidacloprid and the organophosphate acaricide coumaphos. J Insect Physiol 2016;89:1-8. doi: 10.1016/j. jinsphys.2016.03.004

55. Di Prisco G, Cavaliere V, Annoscia D, Varricchio P, Caprio E, Nazzi F, Gargiulo G, Pennacchio F. Neonicotinoid clothianidin adversely affects insect immunity and promotes replication of a viral pathogen in honeybees. P Natl Acad Sci USA 2013;110:18466-71. doi: 10.1073/pnas. 1314923110

56. Wegener J, Ruhnke H, Milchreit K, Kleebaum K, Franke M, Mispagel S, Bischoff G, Kamp G, Bienefeld K. Secondary biomarkers of insecticide-induced stress of honeybee colonies and their relevance for overwintering strength. Ecotoxicol Environ Safe 201;132: 379-89.

57. Tavares DA, Roat TC, Carvalho SM, Silva-Zacarin EC, Malaspina O. In vitro effects of thiamethoxam on larvae of Africanized honeybee Apis mellifera (Hymenoptera: Apidae). Chemosphere 2015;135:370-8. doi: 10.1016/j. chemosphere.2015.04.090

58. Tavares DA, Dussaubat C, Kretzschmar A, Carvalho SM, Silva-Zacarin ECM, Malaspina O, Bérail G, Brunet JL, Belzunces LP. Exposure of larvae to thiamethoxam affects 
the survival and physiology of the honeybee at postembryonic stages. Environ Pollut 2017;229:386-93. doi: 10.1016/j.envpol.2017.05.092

59. Friol PS, Catae AF, Tavares DA, Malaspina O, Roat TC. Can the exposure of Apis mellifera (Hymenoptera, Apiadae) larvae to a field concentration of thiamethoxam affect newly emerged bees? Chemosphere 2017;185:56-66. doi: 10.1016/j. chemosphere.2017.06

60. Peng YC, Yang EC. Sublethal dosage of imidacloprid reduces the microglomerular density of honeybee mushroom bodies. Sci Rep 2016;6:19298. doi: 10.1038/srep19298

61. Yang EC, Chang HC, Wu WY, Chen YW. Impaired olfactory associative behavior of honeybee workers due to contamination of imidacloprid in the larval stage. PLoS One 2012;7:e49472. doi: 10.1371/journal.pone.0049472

62. Wu MC, Chang YW, Lu KH, Yang EC. Gene expression changes in honeybees induced by sublethal imidacloprid exposure during the larval stage. Insect Biochem Molec 2017;88:12-20. doi: 10.1016/j.ibmb.2017.06.016

63. Shi TF, Wang YF, Liu F, Qi L, Yu LS. Influence of the neonicotinoid insecticide thiamethoxam on miRNA expression in the honeybee (Hymenoptera: Apidae). J Insect Sci 2017;17:96. doi: 10.1093/jisesa/iex074

64. Shi TF, Wang YF, Liu F, Qi L, Yu LS. Sublethal effects of the neonicotinoid insecticide thiamethoxam on the transcriptome of the honeybees (Hymenoptera: Apidae). J Econ Entomol 2017;110:2283-9. doi: 10.1093/jee/tox262

65. Abbo PM, Kawasaki JK, Hamilton M, Cook SC, DeGrandiHoffman G, Li WF, Liu J, Chen YP. Effects of Imidacloprid and Varroa destructor on survival and health of European honeybees, Apis mellifera. Insect Sci 2017;24:467-77. doi: 10.1111/1744-7917.12335

66. De Smet L, Hatjina F, Ioannidis P, Hamamtzoglou A, Schoonvaere K, Francis F, Meeus I, Smagghe G, de Graaf DC. Stress indicator gene expression profiles, colony dynamics and tissue development of honeybees exposed to sub-lethal doses of imidacloprid in laboratory and field experiments. PLoS One 2017;12:e0171529. doi: 10.1371/ journal.pone. 0171529

67. Mommaerts V, Reynders S, Boulet J, Besard L, Sterk G, Smagghe G. Risk assessment for side-effects of neonicotinoids against bumblebees with and without impairing foraging behavior. Ecotoxicology 2010;19:207-15. doi: 10.1007/ s10646-009-0406-2

68. Cresswell JE, Page CJ, Uygun MB, Holmbergh M, Li YR, Wheeler JG, Laycock I, Pook CJ, de Ibarra NH, Smirnoff N, Tyler, CR. Differential sensitivity of honeybees and bumble bees to a dietary insecticide (imidacloprid). Zoology 2012;115:365-71. doi: 10.1016/j.zool.2012.05.003

69. Cresswell JE, Robert FX, Florance H, Smirnoff N. Clearance of ingested neonicotinoid pesticide (imidacloprid) in honeybees (Apis mellifera) and bumblebees (Bombus terrestris). Pest Manag Sci 2014;70:332-7. doi: 10.1002/ ps.3569

70. Stanley DA, Russell AL, Morrison SJ, Rogers C, Raine NE. Investigating the impacts of field-realistic exposure to a neonicotinoid pesticide on bumblebee foraging, homing ability and colony growth. J Appl Ecol 2016;53:1440-9. doi: 10.1111/1365-2664.12689

71. Laycock I, Cotterell KC, O'Shea-Wheller TA, Cresswell JE. Effects of the neonicotinoid pesticide thiamethoxam at fieldrealistic levels on microcolonies of Bombus terrestris worker bumble bees. Ecotox Environ Safe 2014;100:153-8. doi: 10.1016/j.ecoenv.2013.10.027

72. Bryden J, Gill RJ, Mitton RA, Raine NE, Jansen VA. Chronic sublethal stress causes bee colony failure. Ecol Lett 2013;16:1463-9. doi: 10.1111/ele.12188

73. Baron GL, Raine NE, Brown MJF. General and speciesspecific impacts of a neonicotinoid insecticide on the ovary development and feeding of wild bumblebee queens. Proc Roy Soc B Biol Sci 2017;284:20170123. doi: 10.1098/ rspb.2017.0123.

74. Czerwinski MA, Sadd B. Detrimental interactions of neonicotinoid pesticide exposure and bumblebee immunity. J Exp Zool Part A 2017;327:273-83. doi: 10.1002/jez.2087

75. Moffat C, Buckland ST, Samson AJ, McArthur R, Chamosa Pino V, Bollan KA, Huang JT, Connolly CN. Neonicotinoids target distinct nicotinic acetylcholine receptors and neurons, leading to differential risks to bumblebees. Sci Rep 2016;6:24764. doi: 10.1038/srep24764

76. Stanley DA, Smith KE, Raine NE. Bumblebee learning and memory is impaired by chronic exposure to a neonicotinoid pesticide. Sci Rep 2015;5:16508. doi:10.1038/srep16508

77. Wilson DE, Velarde RA, Fahrbach SE, Mommaerts V, Smagghe G. Use of primary cultures of Kenyon cells from bumblebee brains to assess pesticide side effects. Arch Insect Biochem 2013;84:43-56. doi: 10.1002/arch.21112

78. Laycock I, Cresswell JE. Repression and recuperation of brood production in Bombus terrestris bumble bees exposed to a pulse of the neonicotinoid pesticide imidacloprid. PLoS One 2013;8: e79872. doi: 10.1371/journal.pone.0079872

79. European Food Safety Authority (EFSA). Review report for the active substance acetamiprid SANCO/1392/2001. OJ L 2004; 145:36.

80. Brunet JL, Badiou A, Belzunces LP. In vivo metabolic fate of $\left[{ }^{14} \mathrm{C}\right]$-acetamiprid in six biological compartments of the honeybee, Apis mellifera L. Pest Manag Sci 2005;61:742-8. doi: 10.1002/ps.1046

81. Badawy MEI, Nasr HM, Rabea EI. Toxicity and biochemical changes in the honeybee Apis mellifera exposed to four insecticides under laboratory conditions. Apidologie 2015;46:177-93. doi: 10.1007/s13592-014-0315-0

82. Stanley J, Sah K, Jain SK, Bhatt JC, Sushil SN. Evaluation of pesticide toxicity at their field recommended doses to honeybees, Apis cerana and A. mellifera through laboratory, semi-field and field studies. Chemosphere 2015;119:668-74. doi: 10.1016/j.chemosphere.2014.07.039

83. Silvina N, Florencia J, Nicolas P, Cecilia P, Lucia P, Abbate S, Leonidas CL, Sebastian D, Yamandu M, Veronica C, Horacio H. Neonicotinoids transference from the field to the hive by honeybees: Towards a pesticide residues biomonitor. Sci Total Environ 2017;581:25-31. doi: 10.1016/j. scitotenv.2017.01.011

84. Arce AN, David TI, Randall EL, Rodrigues AR, Colgan TJ, Wurm Y, Gill RJ. Impact of controlled neonicotinoid exposure on bumblebees in a realistic field setting. J Appl Ecol 2016;54:1199-208. doi: 10.1111/1365-2664.12792

85. Liu Y, Liu S, Zhang H, Gu Y, Li X, He M, Tan H. Application of the combination index (CI)-isobologram equation to research the toxicological interactions of clothianidin, thiamethoxam, and dinotefuran in honeybee, Apis mellifera. Chemosphere 2017;184:806-11. doi: 10.1016/j. chemosphere.2017.06.045 
86. Van der Sluijs JP, Simon-Delso N, Goulson D, Maxim L, Bonmatin JM, Belzunces LP. Neonicotinoids, bee disorders and the sustainability of pollinator services. Curr Opin Env Sust 2013;5:293-305. doi: 10.1016/j.cosust.2013.05.007

87. Retschnig G, Neumann P, Williams GR. Thiacloprid-Nosema ceranae interactions in honeybees: host survivorship but not parasite reproduction is dependent on pesticide dose. $\mathrm{J}$ Invertebr Pathol 2014;118:18-9. doi: 10.1016/j. jip.2014.02.008

88. Alaux C, Brunet JL, Dussaubat C, Mondet F, Tchamitchan S, Cousin M, Brillard J, Baldy A, Belzunces LP, Le Conte Y. Interactions between Nosema microspores and a neonicotinoid weaken honeybees (Apis mellifera). Environ Microbiol $2010 ; 12: 774-82$. doi : 10.1111/j.1462-2920.2009.02123.x

89. Blanken LJ, van Langevelde F, van Dooremalen C. Interaction between Varroa destructor and imidacloprid reduces flight capacity of honeybees. Proc Royal Soc B Biol Sci 2015;282:20151738. doi: 10.1098/rspb.2015.1738

90. Van der Zee R, Gray A, Pisa L, de Rijk T. An observational study of honeybee colony winter losses and their association with Varroa destructor, neonicotinoids and other risk factors. PLoS One 2015;10:e131611. doi: 10.1371/journal. pone. 0131611

91. Vidau C, Diogon M, Aufauvre J, Fontbonne R, Viguès B, Brunet JL, Texier C, Biron DG, Blot N, El Alaoui H, Belzunces LP, Delbac F. Exposure to sublethal doses of fipronil and thiacloprid highly increases mortality of honeybees previously infected by Nosema ceranae. PLoS One 2011;6:e21550. doi: 10.1371/journal.pone.0021550

92. Tosi S, Nieh JC, Sgolastra F, Cabbri R, Medrzycki P. Neonicotinoid pesticides and nutritional stress synergistically reduce survival in honeybees. Proc Roy Soc B Biol Sci 2017;284:20171711. doi: 10.1098/rspb.2017.1711

93. Alburaki M, Boutin S, Mercier PL, Loublier Y, Chagnon M, Derome N. Neonicotinoid-coated Zea mays seeds indirectly affect honeybee performance and pathogen susceptibility in field trials. PLoS One 2015;10:e125790. doi: 10.1371/ journal.pone. 0125790

94. Dance C, Botias C, Goulson D. The combined effects of a monotonous diet and exposure to thiamethoxam on the performance of bumblebee micro-colonies. Ecotox Environ Safe 2017;139:194-201. doi: 10.1016/j.ecoenv.2017.01.041

95. Yue M, Luo S, Liu J, Wu J. Apis cerana is less sensitive to most neonicotinoids, despite of their smaller body mass. J Econ Entomol 2018;111:39-42. doi: 10.1093/jee/tox342

96. Jin N, Klein S, Leimig F, Bischoff G, Menzel R. The neonicotinoid clothianidin interferes with navigation of the solitary bee Osmia cornuta in a laboratory test. J Exp Biol 2015;218:2821-5. doi: 10.1242/jeb.12361

97. Whitehorn PR, Cook N, Blackburn CV, Gill SM, Green J, Shuker DM. Sex allocation theory reveals a hidden cost of neonicotinoid exposure in a parasitoid wasp. Proc Roy Soc B Biol Sci 2015;282:20150389. doi: 10.1098/rspb.2015.0389

98. Thiel S, Kohler HR. A sublethal imidacloprid concentration alters foraging and competition behaviour of ants. Ecotoxicology 2016;25:814-23. doi: 10.1007/s10646-0161638-6

99. Barbieri R, Lester PJ, Miller AS, Ryan KG. A neurotoxic pesticide changes the outcome of aggressive interactions between native and invasive ants. Proc Roy Soc B Biol Sci 2013;280:20132157. doi: 10.1098/rspb.2013.2157
100. Douglas MR, Rohr JR, Tooker JF. Neonicotinoid insecticide travels through a soil food chain, disrupting biological control of non-target pests and decreasing soya bean yield. J Appl Ecol 2015;52:250-60. doi: 10.1111/1365-2664.12372

101. Cavallaro MC, Morrissey CA, Headley JV, Peru KM, Liber K. Comparative chronic toxicity of imidacloprid, clothianidin, and thiamethoxam to Chironomus dilutus and estimation of toxic equivalency factors. Environ Toxicol Chem 2017;36:372-82. doi: 10.1002/etc.3536

102. Saraiva AS, Sarmento RA, Rodrigues ACM, Campos D, Fedorova G, Zlabek V, Gravato C, Pestana JLT, Soares AMVM. Assessment of thiamethoxam toxicity to Chironomus riparius. Ecotox Environ Safe 2017;137:240-6. doi: 10.1016/j.ecoenv.2016.12.00

103. Azevedo-Pereira HMVS, Lemos MFL, Soares AMVM. Effects of imidacloprid exposure on Chironomus riparius Meigen larvae: Linking acetylcholinesterase activity to behaviour. Ecotox Environ Safe 2011;74:1210-15. doi: 10.1016/j.ecoenv.2011.03.018

104. Kobashi K, Harada T, Adachi Y, Mori M, Ihara M, Hayasaka D. Comparative ecotoxicity of imidacloprid and dinotefuran to aquatic insects in rice mesocosms. Ecotox Environ Safe 2017;138:122-9. doi: 10.1016/j.ecoenv.2016.12.025

105. Malev O, Klobučar RS, Fabbretti E, Trebše P. Comparative toxicity of imidacloprid and its transformation product 6-chloronicotinic acid to non-target aquatic organisms: Microalgae Desmodesmus subspicatus and amphipod Gammarus fossarum. Pestic Biochem Phys 2012;104:178-86. doi: 10.1016/j.pestbp.2012.07.008

106. Uğurlu P, Ünlü E, Satar EI. The toxicological effects of thiametoxam on Gammarus kischineffensis (Schellenberg 1937) (Crustacea: Amphipoda). Environ Toxicol Phar 2015;39;720-6. doi: 10.1016/j.etap.2015.01.013

107. Arican C, Traunspurger W, Spann N. The influence of thiacloprid on the feeding behaviour of the copepod, Diacyclops bicuspidatus, preying on nematodes. Nematology 2017;19:1201-15. doi: 10.1163/15685411-00003118

108. Chen C, Wang Y, Zhao X, Wang Q, Qian Y. Comparative and combined acute toxicity of butachlor, imidacloprid and chlorpyrifos on earthworm, Eisenia fetida. Chemosphere 2014;100:111-5. doi: 10.1016/j.chemosphere.2013.12.023

109. Wang K, Pang S, Mu XY, Qi SZ, Li DZ, Cui F, Wang CJ. Biological response of earthworm, Eisenia fetida, to five neonicotinoid insecticides. Chemosphere 2015;132:120-6. doi: 10.1016/j.chemosphere.2015.03.002

110. Lanteigne M, Whiting SA, Lydy MJ. Mixture toxicity of imidacloprid and cyfluthrin to two non-target species, the fathead minnow Pimephales promelas and the amphipod Hyalella azteca. Arch Environ Con Tox 2015;68:354-61. doi: 10.1007/s00244-014-0086-7

111. Chevillot F, Convert Y, Desrosiers M, Cadoret N, Veilleux E, Cabana H, Bellenger JP. Selective bioaccumulation of neonicotinoids and sub-lethal effects in the earthworm Eisenia andrei exposed to environmental concentrations in an artificial soil. Chemosphere 2017;186:839-47. doi: 10.1016/j.chemosphere.2017.08.046

112. Van Hoesel W, Tiefenbacher A, Konig N, Dorn VM, Hagenguth JF, Prah U, Widhalm T, Wiklicky V, Koller R, Bonkowski M, Lagerlöf J, Ratzenböck A, Zaller, JG. Single and combined effects of pesticide seed dressings and herbicides on earthworms, soil microorganisms, and litter 
decomposition. Front Plant Sci 2017;8:215. doi: 10.3389/ fpls.2017.00215

113. Crosby EB, Bailey JM, Oliveri AN, Levin ED. Neurobehavioral impairments caused by developmental imidacloprid exposure in zebrafish. Neurotoxicol Teratol 2015;49:81-90. doi: 10.1016/j.ntt.2015.04.006

114. Iturburu FG, Zömisch M, Panzeri AM, Crupkin AC, Contardo-Jara V, Pflugmacher S, Menone ML. Uptake, distribution in different tissues, and genotoxicity of imidacloprid in the freshwater fish Australoheros facetus. Environ Toxicol Chem 2017;36:699-708. doi: 10.1002/ etc. 3574

115. Ansoar-Rodriguez Y, Christofoletti CA, Correia JE, De Souza RB, Morreira-de-Sousa C, Marcato AC, Bueno OC, Malaspina O, Silva-Zacarin EC, Fontanetti CS. Liver alterations in Oreochromis niloticus (Pisces) induced by insecticide imidacloprid: Histopathology and heat shock protein in situ loclaization. J Environ Sci Heal B 2016;51:8817. doi: $10.1080 / 03601234.2016 .1240559$

116. Xia XH, Xia XP, Huo WR, Dong H, Zhang LX, Chang ZJ. Toxic effects of imidacloprid on adult loach (Misgurnus anguilicaudatus). Environ Toxicol Phar 2016;45:132-9. doi: 10.1016/j.etap.2016.05.030

117. Liu M, Wang G, Zhang SY, Zhong S, Qi GL, Wang CJ, Chuai ML, Lee KKH, Lu DX, Yang XS. From the cover: exposing imidacloprid interferes with neurogenesis through impacting on chick neural tube cell survival. Toxicol Sci 2016;153:13748. doi: 10.1093/toxsci/kfw111

118. Lopez-Antia A, Ortiz-Santaliestra ME, Mougeot F, Mateo R. Imidacloprid-treated seed ingestion has lethal effect on adult partridges and reduces both breeding investment and offspring immunity. Environ Res 2015;136:97-107. doi: 10.1016/j.envres.2014.10.023

119. Gobeli A, Crossley D, Johnson J, Reyna K. The effects of neonicotinoid exposure on embryonic development and organ mass in northern bobwhite quail (Colinus virginianus). Comp Biochem Phys B 2017;195:9-15. doi: 10.1016/j. cbpc.2017.02.001

120. Hussein M, Singh V, Sethi R, Singh AK, Hassan MA. Study on embryonic effects of neonicotinoid insecticide on chick embryos. J Anat Soc India 2014;63:125-9. doi: 10.1016/j. jasi.2014.11.006

121. Hussein M, Singh V. Effect on chick embryos development after exposure to neonicotinoid insecticide imidacloprid. J Anat Soc India 2016;65:83-9. doi: 10.1016/j.jasi.2017.01.012

122. Singh V, Hussein M, Singh AK, Hassan MA, Gupta P. Histological and immunohistochemical changes in cerebellum of chick embryos after exposure to neonicotinoid insecticide imidacloprid. J Anat Soc India 2015;64:122-7. doi: 10.1016/j. jasi.2015.10.014

123. Hirano T, Yanai S, Takada T, Yoneda N, Omotehara T, Kubota N, Minami K, Yamamoto A, Mantani Y, Yokoyama T, Kitagawa H, Hoshi N. NOAEL-dose of a neonicotinoid pesticide, clothianidin, acutely induce anxiety-related behavior with human-audible vocalizations in male mice in a novel environment. Toxicol Lett 2018;282:57-63. doi: 10.1016/j.toxlet.2017.10.010

124. Sun Q, Xiao X, Kim Y, Kim D, Yoon KS, Clark JM, Park Y. Imidacloprid promotes high fat diet-induced adiposity and insulin resistance in male C57BL/6J mice. J Agr Food Chem 2016;64:9293-306. doi: 10.1021/acs.jafc.6b04322
125. Sano K, Isobe T, Yang J, Win-Shwe TT, Yoshikane M, Nakayama SF, Kawashima T, Suzuki G, Hashimoto S, Nohara $\mathrm{K}$, Tohyama $\mathrm{C}$, Maekawa F. In utero and lactational exposure to acetamiprid induces abnormalities in socio-sexual and anxiety-related behaviors of male mice. Front Neurosci-Switz 2016;10:228. doi: 10.3389/fnins.2016.00228

126. De Oliveira IM, Nunes BVF, Barbosa DR, Pallares AM, Faro LRF. Effects of the neonicotinoids thiametoxam and clothianidin on in vivo dopamine release in rat striatum. Toxicol Lett 2010;192:294-7. doi: 10.1016/j. toxlet.2009.11.005

127. Hirano T, Yanai S, Omotehara T, Hashimoto R, Umemura Y, Kubota N, Minami K, Nagahara D, Matsuo E, Aihara Y, Shinohara R, Furuyashiki T, Mantani Y, Yokoyama T, Kitagawa H, Hoshi N. The combined effect of clothianidin and environmental stress on the behavioral and reproductive function in male mice. J Vet Med Sci 2015;77:1207-15. doi: 10.1292/jvms. $15-0188$

128. Kubandova J, Sefcikova Z, Kacmarova M, Burkus J, Cikos S, Koppel J, Fabian D. The effect of neonicotinoids on mouse preimplantation embryo development in vitro. In: Animal Physiology 2016: Proceedings of $12^{\text {th }}$ International Scientific Conference; 13-15 June 2016. Bořetice, Czech Republic. Brno: Mendel University; 2016. p. 151-5.

129. Bal R, Erdogan S, Theophilidis G, Baydas G, Naziroglu M. Assessing the effects of the neonicotinoid insecticide imidacloprid in the cholinergic synapses of the stellate cells of the mouse cochlear nucleus using whole-cell patch-clamp recording. Neurotoxicology 2010;31:113-20. doi: 10.1016/j. neuro.2009.10.004

130. Terayama H, Endo H, Tsukamoto H, Matsumoto K, Umezu M, Kanazawa T, Ito M, Sato T, Naito M, Kawakami S, Fujino Y, Tatemichi M, Sakabe K. Acetamiprid accumulates in different amounts in murine brain regions. Int J Env Res Pub He 2016;13:937. doi: 10.3390/ijerph13100937

131. Chakroun S, Ezzi L, Grissa I, Kerkeni E, Neffati F, Bhouri R, Sallem A, Najjar MF, Hassine M, Mehdi M, Haouas Z, Ben Cheikh H. Hematological, biochemical, and toxicopathic effects of subchronic acetamiprid toxicity in Wistar rats. Environ Sci Pollut R 2106;23: 25191-9. doi: 10.1007/s11356016-7650-9

132. Rodrigues KJA, Santana MB, Do Nascimento JLM, PicancoDiniz DLW, Maues LAL, Santos SN, Ferreira VMM, Alfonso M, Duran R, Faro LRF. Behavioral and biochemical effects of neonicotinoid thiamethoxam on the cholinergic system in rats. Ecotox Environ Safe 2010;73:101-7. doi: 10.1016/j. ecoenv.2009.04.021

133. Yanai S, Hirano T, Omotehara T, Takada T, Yoneda N, Kubota N, Yamamoto A, Mantani Y, Yokoyama T, Kitagawa H, Hoshi N. Prenatal and early postnatal NOAEL-dose clothianidin exposure leads to a reduction of germ cells in juvenile male mice. J Vet Med Sci 2017;79:1196-203. doi: 10.1292/ jvms.17-0154

134. Sekeroglu V, Sekeroglu ZA, Demirhan E. Effects of commercial formulations of deltamethrin and/or thiacloprid on thyroid hormone levels in rat serum. Toxicol Ind Health 2014;30:40-6. doi: 10.1177/0748233712448114

135. Shakthi Devan RK, Prabu PC, Panchapakesan S. Immunotoxicity assessment of sub-chronic oral administration of acetamiprid in Wistar rats. Drug Chem Toxicol 2015;38:328-36. doi: 10.3109/01480545.2014.966382 
136. Ozdemir HH, Kara M, Yumrutas O, Uckardes F, Eraslan E, Demir CF, Bal R. Determination of the effects on learning and memory performance and related gene expressions of clothianidin in rat models. Cogn Neurodynamics 2014;8:4116. doi: 10.1007/s11571-014-9293-1

137. Bal R, Türk G, Yılmaz Ö, Etem E, Kuloğlu T, Baydaş G, Naziroğlu M. Effects of clothianidin exposure on sperm quality, testicular apoptosis and fatty acid composition in developing male rats. Cell Biol Toxicol 2012;28:187-200. doi: 10.1007/s10565-012-9215-0

138. Bal R, Türk G, Tuzcu M, Yilmaz Ö, Kuloğlu T, Gundogdu R, Gür S, Agca A, Ulas M, Cambay Z, Tuzcu Z, Gencoglu H, Guvenc M, Ozsahin AD, Kocaman N, Aslan A, Eten E. Assessment of imidacloprid toxicity on reproductive organ system of adult male rats. J Environ Sci Heal B 2012;47:43444. doi: 10.1080/03601234.2012.663311

139. Hsiao C, Lin CL, Lin TY, Wang SE, Wu CH. Imidacloprid toxicity impairs spatial memory of echolocation bats through neural apoptosis in hippocampal CA1 and medial entorhinal cortex areas. J Econ Entomol 2017;110:447-52. doi: 10.1097/ WNR.0000000000000562

140. Gookin JL, Correa MT, Peters A, Malueg A, Mathews KG, Cullen J, Seiler G. Association of gallbladder mucocele histologic diagnosis with selected drug use in dogs: a matched case-control study. J Vet Intern Med 2015;29:1464-72. doi: 10.1111/jvim. 13649

141. Gunier RB, Bradman A, Harley KG, Kogut K, Eskenazi B. Prenatal residential proximity to agricultural pesticide use and IQ in 7-year-old children. Environ Health Persp 2017;125:057002. doi: 10.1289/EHP504

142. Keil AP, Daniels JL, Hertz-Picciotto I. Autism spectrum disorder, flea and tick medication, and adjustments for exposure misclassification: the CHARGE (Childhood Autism Risks from Genetics and Environment) case-control study. Environ Health-Glob 2014;13:3. doi: 10.1186/1476-069X13-3

143. Forrester MB. Neonicotinoid insecticide exposures reported to six poison centers in Texas. Hum Exp Toxicol 2014;33:56873. doi: $10.1177 / 0960327114522500$

144. Nasuti C, Cantalamessa F, Falcioni G, Gabbianelli R. Different effects of Type I and Type II pyrethroids on erythrocyte plasma membrane properties and enzymatic activity in rats. Toxicology 2003;191:233-44. doi: 10.1016/ S0300-483X(03)00207-5

145. Ye J, Zhao M, Niu L, Liu W. Enantioselective environmental toxicology of chiral pesticides. Chem Res Toxicol 2015;28:325-38. doi: 10.1021/tx500481n

146. Peng W, Ding F. Enantioselective recognition of an isomeric ligand by a biomolecule: mechanistic insights into static and dynamic enantiomeric behavior and structural flexibility. Mol BioSyst 2017;13:2226-34. doi: 10.1039/C7MB00378A

147. Yang ZH, Ji GD. Enantioselective degradation mechanism of beta-cpermethrin in soil from the perspective of functional genes. Chirality 2015;27:929-35. doi: 10.1002/chir.22504

148. De Albuquerque NCP, Carrão DB, Habenschus DB, de Oliveira ARM. Metabolism studies of chiral pesticides: A critical review. J Pharmaceut Biomed 2018;147:89-109. doi: 10.1016/j.jpba.2017.08.011

149. He XM, Dong XW, Zou DH, Yu Y, Fang QY, Zhang Q, Zhao MR. Enantioselective effects of $o, p$ '-DDT on cell invasion and adhesion of breast cancer cells: chirality in cancer development. Environ Sci Technol 2015;49:10028-37. doi: 10.1021/acs.est.5b02147

150. Chang J, Hao WY, Xu YY, Xu P, Li W, Li JZ, Wang HL. Stereoselective degradation and thyroid endocrine disruption of lambda-cyhalothrin in lizards (Eremias argus) following oral exposure. Environ Pollut 2018;232:300-9. doi: 10.1016/j. envpol.2017.09.072

151. Wu C, Huang L, Tang S, Li Z, Ye Q. Enantioselective absorption and transformation of a novel chiral neonicotinoid $\left[{ }^{14} \mathrm{C}\right]$-cycloxaprid in rats. Environ Pollut 2016;213:770-5. doi: 10.1016/j.envpol.2016.03.037

152. Bendahou N, Bounias M, Fleche C. Toxicity of Cypermethrin and Fenitrothion on the Hemolymph Carbohydrates, Head Acetylcholinesterase, and Thoracic Muscle $\mathrm{Na}^{+}, \mathrm{K}^{+}$-ATPase of Emerging Honeybees (Apis mellifera mellifera. $\mathrm{L}$ ). Ecotox Environ Safe 1999;44:139-46. doi: 10.1006/eesa.1999.1811

153. Christen V, Fent K. Exposure of honeybees (Apis mellifera) to different classes of insecticides exhibit distinct molecular effect patterns at concentrations that mimic environmental contamination. Environ Pollut 2017;226:48-59. doi: 10.1016/j.envpol.2017.04.003

154. Kunce W, Stoks R, Johansson F. Single and mixture impacts of two pyrethroids on damselfly predatory behavior and physiological biomarkers. Aquat Toxicol 2017;190:70-7. doi: 10.1016/j.aquatox.2017.06.025

155. Pristed MJS, Bundschuh M, Rasmussen JJ. Multiple exposure routes of a pesticide exacerbate effects on a grazing mayfly. Aquat Toxicol 2016;178:190-6. doi: 10.1016/j. aquatox.2016.08.005

156. Zanardi OZ, Bordini GP, Franco AA, Jacob CRO, Yamamoto PT. Sublethal effects of pyrethroid and neonicotinoid insecticides on Iphiseiodes zuluagai Denmark and Muma (Mesostigmata: Phytoseiidae). Ecotoxicology 2017;26:118898. doi: 10.1007/s10646-017-1844-x

157. Gutierrez Y, Tome HVV, Guedes RNC, Oliveira EE. Deltamethrin toxicity and impaired swimming behavior of two backswimmer species. Environ Toxicol Chem 2017;36:1235-42. doi: 10.1002/etc.3645

158. Hoffmann KC, Deanovic L, Werner I, Stillway M, Fong S, Teh S. An analysis of lethal and sublethal interactions among type I and type II pyrethroid pesticide mixtures using standard Hyalella azteca water column toxicity tests. Environ Toxicol Chem 2016;35:2542-9. doi: 10.1002/etc.3422

159. Gottardi M, Birch MR, Dalhoff K, Cedergreen N. The effects of epoxiconazole and $\alpha$-cypermethrin on Daphnia magna growth, reproduction and offspring size. Environ Toxicol Chem 2017;36:2155-66. doi: 10.1002/etc.3752

160. Hasenbein S, Lawler SP, Geist J, Connon RE. A long-term assessment of pesticide mixture effects on aquatic invertebrate communities. Environ Toxicol Chem 2016;35:218-32. doi: 10.1002/etc. 3187

161. Cheng F, Li HZ, Qi HX, Han Q, You J. Contribution of pyrethroids in large urban rivers to sediment toxicity assessed with benthic invertebrates Chironomus dilutus: A case study in South China. Environ Toxicol Chem 2017;36:3367-75. doi: 10.1002/etc.3919

162. Tu WQ, Xu C, Jin YX, Lu B, Lin CM, Wu YM, Liu WP. Permethrin is a potential thyroid-disrupting chemical: In vivo and in silico evidence. Aquat Toxicol 2016;175:39-46. doi: 10.1016/j.aquatox.2016.03.006

163. Fai PBA, Kinfack JST, Towa YJT. Acute effects of binary mixtures of Type II pyrethroids and organophosphate 
insecticides on Oreochromis niloticus. Ecotoxicology 2017;26:889-901. doi: 10.1007/s10646-017-1819-y

164. Radovanović TB, Nasia M, Krizmanić II, Prokić MD, Gavrić JP, Despotović SG, Gavrilović BR, Borković-Mitić SS, Pavlović SZ, Saičić ZS. Sublethal effects of the pyrethroid insecticide deltamethrin on oxidative stress parameters in green toad (Bufotes viridis L.). Environ Toxicol Chem 2017;36:2814-22. doi: 10.1002/etc.3849

165. Chauhan LKS, Varshney M, Pandey V, Sharma P, Verma VK, Kumar P, Goel SK. ROS-dependent genotoxicity, cell cycle perturbations and apoptosis in mouse bone marrow cells exposed to formulated mixture of cypermethrin and chlorpyrifos. Mutagenesis 2016;31:635-42. doi: 10.1093/ mutage/gew031

166. Bardullas U, Sosa-Holt CS, Pato AM, Nemirovsky SI, Wolansky MJ. Evidence for effects on thermoregulation after acute oral exposure to type I and type II pyrethroids in infant rats. Neurotoxicol Teratol 2015;52:1-10. doi: 10.1016/j. ntt.2015.09.005

167. Moser VC, Liu ZW, Schlosser C, Spanogle TL, Chandrasekaran A, McDaniel KL. Locomotor activity and tissue levels following acute administration of lambda- and gamma-cyhalothrin in rats. Toxicol Appl Pharm 2016;313:97103.

168. Wang P, Xu MY, Liang YJ, Wang HP, Sun YJ, Long DX, Wu YJ. Subchronic toxicity of low dose propoxur, permethrin, and their combination on the redox status of rat liver. ChemmBiol Interact 2017;272:21-7. doi: 10.1016/j.cbi.2017.04.023

169. Bordoni L, Nasuti C, Mirto M, Caradonna F, Gabbianelli R. Intergenerational effect of early life exposure to permethrin: changes in global DNA methylation and in Nurrl gene expression. Toxics 2015;3:451-61. doi: 10.3390/ toxics3040451

170. Bordoni L, Fedeli D, Nasuti C, Capitani M, Fiorini D, Gabbianelli R. Permethrin pesticide induces NURR1 upregulation in dopaminergic cell line: Is the pro-oxidant effect involved in toxicant-neuronal damage? Comp Biochem Phys C 2017;201:51-7. doi: 10.1016/j.cbpc.2017.09.006

171. Saillenfait AM, Ndiaye D, Sabate JP, Denis F, Antoine G, Robert A, Rouiller-Fabre V, Moison D. Evaluation of the effects of deltamethrin on the fetal rat testis. J Appl Toxicol 2016;36:1505-15. doi: 10.1002/jat.3310

172. Syed F, John PJ, Soni I. Neurodevelopmental consequences of gestational and lactational exposure to pyrethroids in rats. Environ Toxicol 2016;31:1761-70. doi: 10.1002/tox.22178

173. Amaraneni M, Pang J, Mortuza TB, Muralidhara S, Cummings BS, White CA, Vorhees CV, Zastre J, Bruckner JV. Brain uptake of deltamethrin in rats as a function of plasma protein binding and blood-brain barrier maturation. Neurotoxicology 2017;62:24-9. doi: $10.1016 / \mathrm{j}$. neuro.2017.04.009

174. Madhubabu G, Yenugu S. Allethrin toxicity causes reproductive dysfunction in male rats. Environ Toxicol 2017;32:1701-10. doi: 10.1002/tox.22394

175. Magby JP, Richardson JR. Role of calcium and calpain in the downregulation of voltage-gated sodium channel expression by the pyrethroid pesticide deltamethrin. J Biochem Mol Toxicol 2015;29:129-34. doi: 10.1002/ jbt. 21676

176. Wang B, Liu JJ, Wang Y, Fu L, Shen R, Yu Z, Wang H, Chen YH, Zhang C, Meng XH, Xu DX. Maternal fenvalerate exposure induces fetal intrauterine growth restriction through disrupting placental thyroid hormone receptor signaling. Toxicol Sci 2017;157:377-86. doi: 10.1093/toxsci/kfx052

177. Ye XQ, Li FX, Zhang JY, Ma HH, Ji DP, Huang X, Curry TE, Liu WP, Liu J. Pyrethroid insecticide cypermethrin accelerates pubertal onset in male mice via disrupting hypothalamic-pituitary-gonadal axis. Environ Sci Technol 2017;51:10212-21. doi: 10.1021/acs.est.7b02739

178. Vardavas AI, Stivaktakis PD, Tzatzarakis MN, Fragkiadaki P, Vasilaki F, Tzardi M, Datseri G, Tsiaoussis J, Alegakis AK, Tsitsimpikou C, Rakitskii VN, Carvalho F, Tsatsakis AM. Long-term exposure to cypermethrin and piperonyl butoxide cause liver and kidney inflammation and induce genotoxicity in New Zealand white male rabbits. Food Chem Toxicol 2016;94:250-9. doi: 10.1016/j.fct.2016.06.016

179. Vidi PA, Anderson KA, Chen HY, Anderson R, SalvadorMoreno N, Mora DC, Poutasse C, Laurienti PJ, Daniel SS, Arcury TA. Personal samplers of bioavailable pesticides integrated with a hair follicle assay of DNA damage to assess environmental exposures and their associated risks in children. Mutat Res-Gen Tox En 2017;822:27-33. doi: 10.1016/j.mrgentox.2017.07.003

180. Trueblood AB, Forrester MB, Han D, Shipp EM, Cizmas LH. Pesticide-related poison center exposures in children and adolescents aged $\leq 19$ years in Texas, 2000-2013. Clin Toxicol 2016;54:852-6. doi: 10.1080/15563650.2016.1201676

181. Campos E, Da Silva VDP, De Mello MSC, Otero UB. Exposure topesticides and mental disorders in a rural population of Southern Brazil. Neurotoxicology 2016;56:716. doi: 10.1016/j.neuro.2016.06.002

182. Furlong MA, Barr DB, Wolff MS, Engel SM. Prenatal exposure to pyrethroid pesticides and childhood behavior and executive functioning. Neurotoxicology 2017;62:231-8. doi: 10.1016/j.neuro.2017.08.005

183. Schmidt RJ, Kogan V, Shelton JF, Delwiche L, Hansen RL, Ozonoff S, Ma CC, McCanlies EC, Bennett DH, HertzPicciotto I, Tancredi DJ, Volk HE. Combined prenatal pesticide exposure and folic acid intake in relation to autism spectrum disorder. Environ Health Persp 2017;125:097007. doi: 10.1289/EHP604

184. Manyilizu WB, Mdegela RH, Kazwala R, Nonga H, Muller M, Lie E, Skjerve E, Lyche JL. Association of long-term pesticide exposure and biologic parameters in female farm workers in Tanzania: A cross sectional study. Toxics 2016;4:25. doi: 10.3390/toxics4040025

185. Botnariu G, Birsan C, Podoleanu C, Moldovan C, Stolnicu $\mathrm{S}$, Chiriac A. Skin necrosis caused by prallethrin A worldwide used insecticide. Environ Toxicol Phar 2016;43:103-4. doi: 10.1016/j.etap.2016.03.002

186. Martenies SJ, Perry MJ. Environmental and occupational pesticide exposure and human sperm parameters: a systematic review. Toxicology 2017;307:66-73. doi: 10.1016/j. tox.2013.02.005

187. Chiu YH, Gaskins AJ, Williams PL, Mendiola J, Jørgensen $\mathrm{N}$, Levine H, Hauser R, Swan SH, Chavarro JE. Intake of fruits and vegetables with low-to-moderate pesticide residues is positively associated with semen-quality parameters among young healthy men. J Nutr 2017;146:1084-92. doi: 10.3945/ jn. 115.226563

188. Ye X, Pan W, Zhao S, Zhao Y, Zhu Y, Liu J, Liu W. Relationships of pyrethroid exposure with gonadotropin levels and pubertal development in Chinese boys. Environ Sci Technol 2017;51:6379-86. doi: 10.1021/acs.est.6b05984 
189. Gupta S, Gupta R, Sharma S. Impact of pesticides on plant growth promotion of Vigna radiata and non-target microbes: comparison between chemical- and bio-pesticides. Ecotoxicology 2014;23:1015-21. doi: 10.1007/s10646-014$1245-3$

190. Kreutzweiser DP, Capell SS, Scarr TA. Community-level responses by stream insects to neem products containing azadirachtin. Environ Toxicol Chem 2000;19:855-61. doi: 10.1002/etc.5620190411

191. Kreutzweiser DP, Back RC, Sutton TM, Pangle KL, Thompson DG. Aquatic mesocosm assessments of a neem (azadirachtin) insecticide at environmentally realistic concentrations - 2: zooplankton community responses and recovery. Ecotoxicol Environ Safe 2004;59:194-204. doi: 10.1016/j.ecoenv.2003.09.008

192. Kreutzweiser DP, Sutton TM, Back RC, Pangle KL, Thompson DG. Some ecological implications of a neem (azadirachtin) insecticide disturbance to zooplankton communities in forest pond enclosures. Aquat Toxicol 2004;67:239-54. doi: 10.1016/j.aquatox.2004.01.011

193. Kreutzweiser DP, Back RC, Sutton TM, Thompson DG, Scarr TA. Community-level disruptions among zooplankton of pond mesocosms treated with a neem (azadirachtin) insecticide. Aquat Toxicol 2002;56:257-73. doi: 10.1016/ S0166-445X(01)00216-8

194. Goktepe I, Plhak LC. Comparative toxicity of two azadirachtin-based neem pesticides to Daphnia pulex. Environ Toxicol Chem 2002;21:31-6. doi: 10.1002/ etc. 5620210105

195. Barbosa WF, De Meyer L, Guedes RNC, Smagghe G. Lethal and sublethal effects of azadirachtin on the bumblebee Bombus terrestris (Hymenoptera: Apidae). In: Oomen PA, Pistorius J, editors. Hazards of Pesticides to Bees: $12^{\text {th }}$ international Symposium of the ICP-PR Bee Protection Group; 15-17 September 2014. Ghent, Belgium. Julius-KühnArchiv 2015;450:180-90.

196. Scudeler EL, Garcia ASG, Padovani CR, Santos DC. Action of neem oil (Azadirachta indica A. Juss) on cocoon spinning in Ceraeochrysa claveri (Neuroptera: Chrysopidae). Ecotox Environ Safe 2013;97:176-82. doi: 10.1016/j. ecoenv.2013.08.008

197. Chandra P, Khuda-Bukhsh AR. Genotoxic effects of cadmium chloride and azadirachtin treated singly and in combination in fish. Ecotox Environ Safe 2004;58:194-201. doi: 10.1016/j. ecoenv.2004.01.010

198. Murussi CR, Menezes CC, Nunes MEM, Araujo MDS, Quadros VA, Rosemberg DB, Loro VL. Azadirachtin, a neem-derived biopesticide, impairs behavioral and hematological parameters in carp (Cyprinus Carpio). Environ Toxicol 2016;31:1381-8. doi: 10.1002/tox.22143

199. Maitra B, Sen S, Homechaudhuri S. Flow cytometric analysis of fish leukocytes as a model for toxicity produced by azadirachtin-based bioagrocontaminant. Toxicol Environ Chem 2014;96:328-41. doi: 10.1080/02772248.2014.934026

200. Kumar A, Prasad M, Suzuki N, Srivastav SK, Srivastav AK. Influence of a botanical pesticide, azadirachtin, on ultimobranchial gland of the freshwater catfish Heteropneustes fossilis. Toxicol Environ Chem 2013;95:1702-11. doi: 10.1080/02772248.2014.895365

201. Bernardi MM, Dias SG, Barbosa VE. Neurotoxicity of neem commercial formulation (Azadirachta indica A. Juss) in adult zebrafish (Danio rerio). Environ Toxicol Phar 2013;36:127682. doi: $10.1016 /$ j.etap.2013.10.002

202. Khan PK, Awasthy KS. Cytogenetic toxicity of neem. Food Chem Toxicol 2003;41:1325-8. doi: 10.1016/S02786915(03)00123-6

203. Scott RH, O'Brien K, Roberts L, Mordue W, Mordue J. Extracellular and intracellular actions of azadirachtin on the electrophysiological properties of cultured rat DRG neurones. Comp Biochem Phys C 1999;123:85-93. doi: 10.1016/S07428413(99)00014-6

204. Rahman MF, Siddiqui MKJ, Jamil K. Effects of Vepacide (Azadirachta indica) on aspartate and alanine aminotransferase profiles in a subchronic study with rats. Hum Exp Toxicol 2001;20:243-9. doi: 10.1191/096032701678227730

205. Rahman MF, Siddiqui MKJ. Biochemical effects of Vepacide (from Azadirachta indica) on Wistar rats during subchronic exposure. Ecotox Environ Safe 2004;59:332-9. doi: 10.1016/j.ecoenv.2003.07.013

206. Srivastava MK, Raizada RB. Assessment of embryo/ fetotoxicity and teratogenicity of azadirachtin in rats. Food Chem Toxicol 2001;39:1023-7. doi: 10.1016/S02786915(01)00047-3

207. Raizada RB, Srivastava MK, Kaushal RA, Singh RP. Azadirachtin, a neem biopesticide: subchronic toxicity assessment in rats. Food Chem Toxicol 2001;39:477-83. doi: 10.1016/S0278-6915(00)00153-8

208. Mosesso P, Bohm L, Pepe G, Fiore M, Carpinelli A, Gade G, Nagini S, Ottavianelli A, Degrassi F. Cytogenetic analyses of Azadirachtin reveal absence of genotoxicity but marked antiproliferative effects in human lymphocytes and $\mathrm{CHO}$ cells in vitro. Toxicol Lett 2012;213:361-6. doi: 10.1016/j. toxlet.2012.07.021

209. Mancebo A, Hernandez O, Gonzalez Y, Aldana L, Carballo O. Assessment of skin and eye irritation of 14 products under the stepwise approach of the OECD. Cutan Ocul Toxicol 2008;27:173-85. doi: 10.1080/15569520701712984

210. Iyyadurai R, Surekha V, Sathyendra S, Wilson BP, Gopinath KG. Azadirachtin poisoning: a case report. Clin Toxicol 2010;48:857-8. doi: 10.3109/15563650.2010.518148

211. Krupke CH, Holland JD, Long EY, Eitzer BD. Planting of neonicotinoid-treated maize poses risks for honeybees and other non-target organisms over a wide area without consistent crop yield benefit. J Appl Ecol 2017;54:1449-58. doi: 10.1111/1365-2664.12924

212. Nakasu EY, Williamson SM, Edwards MG, Fitches EC, Gatehouse JA, Wright GA, Gatehouse AM. Novel biopesticide based on a spider venom peptide shows no adverse effects on honeybees. Proc Roy Soc B 2014;281:1787. doi: 10.1098/rspb.2014.0619 


\section{Neciljana toksičnost novih insekticida}

Ljudi su upotrebljavali insekticide od davnih vremena. Spektar i potentnost dostupnih insekticidnih supstancija značajno su se proširili od industrijske revolucije, vodeći širokoj upotrebi i neviđenim količinama sintetskih kemikalija u okolišu. Zbog toksičnih učinaka tih novih kemikalija na neciljane vrste javnost je ubrzo pokazala veliku zabrinutost, što je dovelo do ograničenja u korištenju tih insekticidnih supstancija. Istovremeno dolazi do razvoja novih metoda u održivoj poljoprivredi, među kojima i razvoj novih insekticida na osnovi prirodno prisutnih kemikalija, poput piretroida (derivati piretrina iz suncokreta) i neonikotinoida (derivati nikotina). Dodatni su primjer insekticidi na bazi biljnog ulja iz drveta nima (Azadirachta indica), dominantno azadiraktin. Iako su te nove supstancije selektivnije prema insektima, poteškoće nastaju s njihovom neciljanom toksičnošću, poput one neonikotinoida, koji su utjecali na pad populacije pčela na globalnoj razini. Ovaj pregled sažima nedavnu literaturu o neciljanoj toksičnosti neonikotinoida, piretroida i insekticidnih supstancija na bazi nima, s naglaskom na toksičnosti neonikotinoida za pčele. Također ćemo se dotaknuti učinaka mješavina pesticida, kao i zabilježene ljudske izloženosti tim supstancijama.

KLJUČNE RIJEČI: neonikotinoidi; piretroidi; nim; azadiraktin; neciljana toksičnost 